\title{
First steps towards a floral structural characterization of the major rosid subclades
}

\author{
Endress, P K ; Matthews, M L
}

\begin{abstract}
A survey of our own comparative studies on several larger clades of rosids and over 1400 original publications on rosid flowers shows that floral structural features support to various degrees the supraordinal relationships in rosids proposed by molecular phylogenetic studies. However, as many apparent relationships are not yet well resolved, the structural support also remains tentative. Some of the features that turned out to be of interest in the present study had not previously been considered in earlier supraordinal studies. The strongest floral structural support is for malvids (Brassicales, Malvales, Sapindales), which reflects the strong support of phylogenetic analyses. Somewhat less structurally supported are the COM (Celastrales, Oxalidales, Malpighiales) and the nitrogen-fixing (Cucurbitales, Fagales, Fabales, Rosales) clades of fabids, which are both also only weakly supported in phylogenetic analyses. The sister pairs, Cucurbitales plus Fagales, and Malvales plus Sapindales, are structurally only weakly supported, and for the entire fabids there is no clear support by the present floral structural data. However, an additional grouping, the COM clade plus malvids, shares some interesting features but does not appear as a clade in phylogenetic analyses. Thus it appears that the deepest split within eurosidsthat between fabids and malvids - in molecular phylogenetic analyses (however weakly supported) is not matched by the present structural data. Features of ovules including thickness of integuments, thickness of nucellus, and degree of ovular curvature, appear to be especially interesting for higher level relationships and should be further explored. Although features of interest are not necessarily stable at the level of a large clade, they do show a considerable concentration in particular clades and are rare or lacking in others. This may be viewed as a special trend for this feature to evolve in this group or to be conserved as a synapomorphy (or a combination of both)
\end{abstract}

DOI: https://doi.org/10.1007/s00606-006-0444-7

Posted at the Zurich Open Repository and Archive, University of Zurich ZORA URL: https://doi.org/10.5167/uzh-155761

Journal Article

Published Version

Originally published at:

Endress, P K; Matthews, M L (2006). First steps towards a floral structural characterization of the major rosid subclades. Plant Systematics and Evolution, 260(2-4):223-251.

DOI: https://doi.org/10.1007/s00606-006-0444-7 


\title{
First steps towards a floral structural characterization of the major rosid subclades
}

\author{
P. K. Endress and M. L. Matthews \\ Institute of Systematic Botany, University of Zurich, Switzerland \\ Received November 3, 2005; accepted January 23, 2006 \\ Published online: July 20, 2006 \\ (c) Springer-Verlag 2006
}

\begin{abstract}
A survey of our own comparative studies on several larger clades of rosids and over 1400 original publications on rosid flowers shows that floral structural features support to various degrees the supraordinal relationships in rosids proposed by molecular phylogenetic studies. However, as many apparent relationships are not yet well resolved, the structural support also remains tentative. Some of the features that turned out to be of interest in the present study had not previously been considered in earlier supraordinal studies. The strongest floral structural support is for malvids (Brassicales, Malvales, Sapindales), which reflects the strong support of phylogenetic analyses. Somewhat less structurally supported are the COM (Celastrales, Oxalidales, Malpighiales) and the nitrogen-fixing (Cucurbitales, Fagales, Fabales, Rosales) clades of fabids, which are both also only weakly supported in phylogenetic analyses. The sister pairs, Cucurbitales plus Fagales, and Malvales plus Sapindales, are structurally only weakly supported, and for the entire fabids there is no clear support by the present floral structural data. However, an additional grouping, the COM clade plus malvids, shares some interesting features but does not appear as a clade in phylogenetic analyses. Thus it appears that the deepest split within eurosids-that between fabids and malvids - in molecular phylogenetic analyses (however weakly supported) is not matched by the present structural data. Features of ovules including thickness of
\end{abstract}

integuments, thickness of nucellus, and degree of ovular curvature, appear to be especially interesting for higher level relationships and should be further explored. Although features of interest are not necessarily stable at the level of a large clade, they do show a considerable concentration in particular clades and are rare or lacking in others. This may be viewed as a special trend for this feature to evolve in this group or to be conserved as a synapomorphy (or a combination of both).

Key words: Rosids, eurosids, fabids, malvids, nitrogen-fixing clade, supraordinal relationships, floral structure, ovules.

\section{Introduction}

In the past decade new results of molecular phylogenetic studies have brought tremendous progress in our perception of plant relationships at all hierarchical levels. In the framework of the eudicots, which were established in morphological cladistic studies (Donoghue and Doyle 1989, Doyle and Hotton 1991) slightly before the onset of the ground breaking molecular works, orders were newly circumscribed, and some quite substantially. Also there are new assemblages of orders that constitute formerly unrecognized large clades 
(outlined in APG 2003, Soltis et al. 2005). The content of the rosids (in the premolecular era called Rosidae, Rosiflorae, or Rosanae, Dahlgren 1980, Cronquist 1981, Takhtajan 1987, Thorne 1992) has considerably changed.

In great contrast to the progress in molecular phylogenetic research, understanding of structural features, not only for these newly circumscribed large clades but also for lower levels, orders, families, and genera, has not advanced to the same degree. New structural characters must be explored that have not been discussed before in macrosystematic studies, and likewise characters that were earlier used should be probed for new large clades.

Rosids are a very large clade including about $30 \%$ of all angiosperm species. The clade contains 14 mainly large orders, most of which are well supported by molecular phylogenetic studies (Soltis et al. 2000, 2005; APG 2003; Judd and Olmstead 2004; Schönenberger and von Balthazar 2006). However, it is unclear for most of these orders how they are related to each other (Fig. 1). Thus, despite impressive progress in some respects, the process of phylogenetic elucidation is only at its beginning.

Two major clusters of orders appear moderately to well supported as clades in molecular studies: fabids (=eurosids I), and malvids (= eurosids II). Within fabids there are

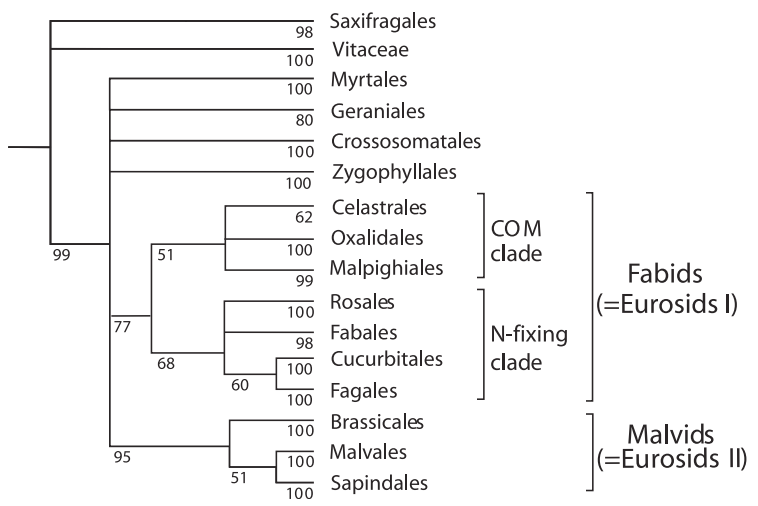

Fig. 1. Cladogram of rosids plus potential sisters (Saxifragales and Vitaceae) (modified after APG 2003 and Soltis et al. 2005, with jackknife values from Soltis et al. 2005) two subclusters, which receive weaker support: the "nitrogen-fixing clade" (Cucurbitales, Fagales, Fabales, Rosales) and the "COM" clade (Celastrales, Oxalidales, and Malpighiales). Within the "nitrogen-fixing clade", Cucurbitales and Fagales appear as sisters. A small order, Zygophyllales (Zygophyllaceae and Krameriaceae) appears as sister to fabids in some analyses but with less than $50 \%$ support (Soltis et al. 2005); therefore we leave it in an unresolved position in rosids in our figures. Within malvids, Malvales and Sapindales appear as sisters, both with weak support (APG 2003, Soltis et al. 2005). The difficulties that have been encountered when trying to resolve the phylogenetic topology at various levels may have been caused by the probable rapid early diversification of rosids and some of their subclades in the Cretaceous (e.g. Davis et al. 2005, Soltis et al. 2005), and perhaps, in addition, because of the large size of these clades, which may need more extensive sampling.

These apparent largest subclades of the rosids are new and have never been considered as clades before. Their sheer size makes their structural characterization a massive task, and in fact, a structural characterization has not yet been performed (see also Stevens 2001 onwards).

This study is an attempt to make a first step towards this goal. We concentrate on the highest levels within rosids: assemblages of orders (but also this at different levels), while considering all current orders for data collection, including Saxifragales and Vitaceae as potential sister groups of rosids. Our study is based on two sources: (1) the studies on several orders of rosids that we carried out over the past five years (Matthews et al. 2001; Schönenberger et al. 2001; Matthews and Endress 2002, 2004, 2005a, b, 2006, Endress 2005; Endress and Matthews 2006) plus our earlier studies in other rosids and putative sister groups (Endress 1967, 1977, 1989; Endress et al. 1983; Hufford and Endress 1989; Endress and Stumpf 1990, 1991; Sutter and Endress 1995; Merino Sutter and Endress 2003; Blarer 
et al. 2004; Merino Sutter et al. 2006) and (2) a search of over 1400 publications with original information throughout all orders of rosids. Our studies of several orders (Matthews and Endress 2002, 2004, 2005a, b, 2006; Matthews et al. 2001; Schönenberger et al. 2001) acquainted us with some idiosyncrasies and features of potential interest. We have mainly concentrated on these features in our literature search. The publications are on systematics, floral structure and embryology. It was not sufficient to use published compilations of data on morphology and embryology. Although handbooks on systematic embryology, such as Schnarf (1931b), Davis (1966), and Johri et al. (1992), are highly useful for a quick survey on familial characters, these works were only used for a compilation of original literature, and not as a source for structural data. The bibliography by Nagendran and Dinesh (1989) was also used. By the study of the illustrations in the original literature and from our own work we found some features of systematic relevance for which the classical embryological terminology is not sufficiently differentiated, and therefore specific mention of these features is lacking in the text of such publications (see also Endress 2003, 2005). In addition, one must be cautious even with the use of primary literature as terms are not always used in the same way. This is another reason to carefully check the illustrations and not only the text. It is of course not possible to cite every single piece of literature used in the present publication. However, we try to cite at least one publication for each feature and taxon mentioned (of the focused groups), and preferably one of the more recent ones.

The goal of this study is to find new features that represent idiosyncrasies of these clades and that are also interesting from an evolutionary point of view, thus helping to better understand the biology of these clades. It is not to find new features for use in a "determination key" for large clades.

Circumscription of the families is according to APG (2003), with some modifications following additional new molecular phylogenetic results (partly discussed in Soltis et al. 2005). To Saxifragales, Cynomoriaceae (Nickrent et al. 2005) and Peridiscaceae (including Soyauxia) (Davis and Chase 2004) are added. To Malpighiales, Rafflesiaceae are added (Barkman et al. 2004, Nickrent et al. 2004), and to malvids, Dipentodontaceae (Peng et al. 2003), Tapisciaceae (Simmons et al. 1998; Savolainen et al. 2000; Soltis et al. 2000, 2005), and Perrottetia (Zhang and Simmons, in press) are added (but outside of the three major orders). Among Brassicales, Brassicaceae are subdivided into Brassicaceae, Capparaceae and Cleomaceae (Hall et al. 2002). To Malvales, Apodanthaceae and Cytinaceae are added (Barkman et al. 2004, Nickrent et al. 2004).

\section{Results}

Malvids ( = Eurosids II)

Campylotropous ovules and zig-zag micropyle (Fig. 2). In campylotropous ovules, in contrast to anatropous ovules, the curvature encompasses not only the ovular base up to the chalazal region, but also the upper part of the ovule. As a consequence, the nucellus and the embryo sac becomes curved. Commonly, a campylotropous ovule has an anatropous shape in early development before further curving. In many cases, the campylotropous form appears only after fertilization, during seed development (e.g. in part of Fabaceae and part of Malvaceae) (Bouman and Boesewinkel 1991). In this paper only ovules are considered as campylotropous that show this shape at the time of fertilization.

In angiosperms, campylotropous ovules are often associated with a zig-zag micropyle. This type of micropyle is formed by both integuments, and in a median longitudinal section the micropylar canal is not straight but zig-zag-shaped. The outer integument exhibits excessive growth and overgrows the micropylar part of the inner integument such that the micropylar part of the outer integument becomes displaced towards the funicle. 
An "inverse zig-zag micropyle" also exists in ropous ovules but occurs rarely in anatrowhich the zig-zag-shape goes in the opposite direction; however, it is absent in campylotpous ovules (e.g. Batis, Bataceae, Alimova 1985a).

2

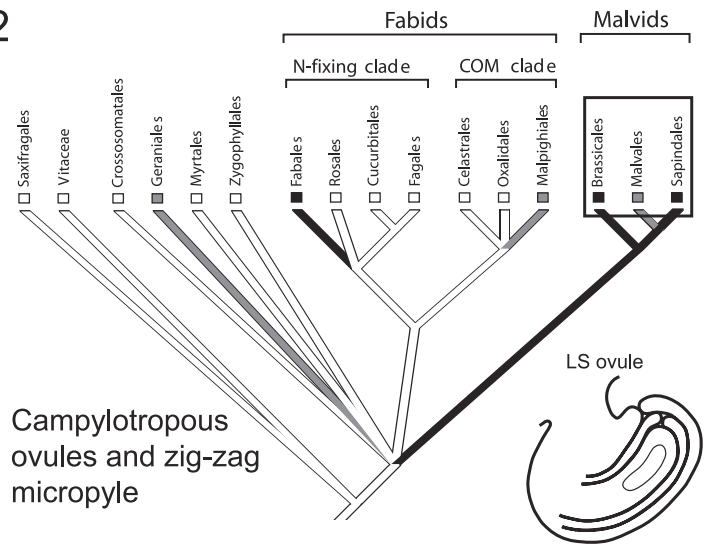

4

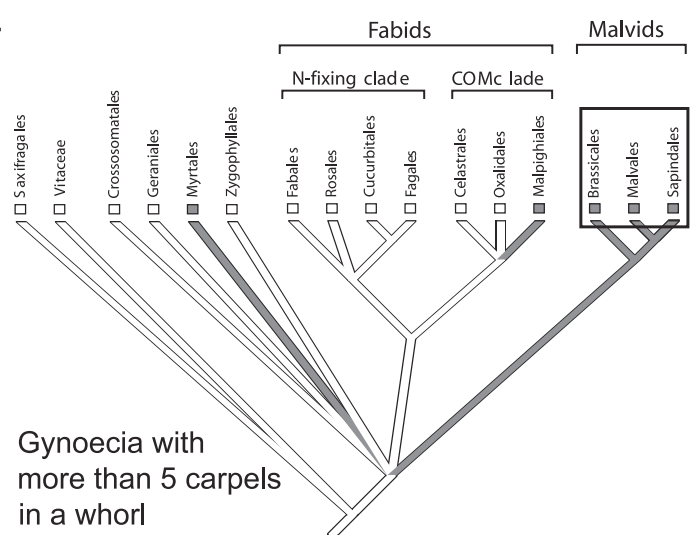

6

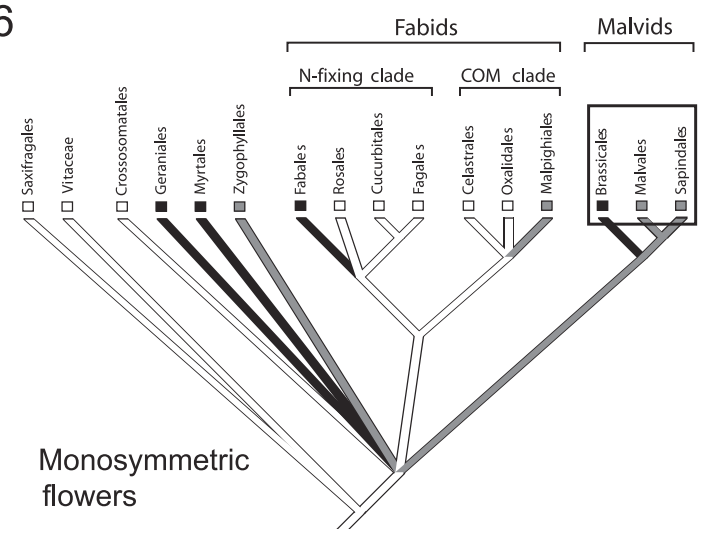

3

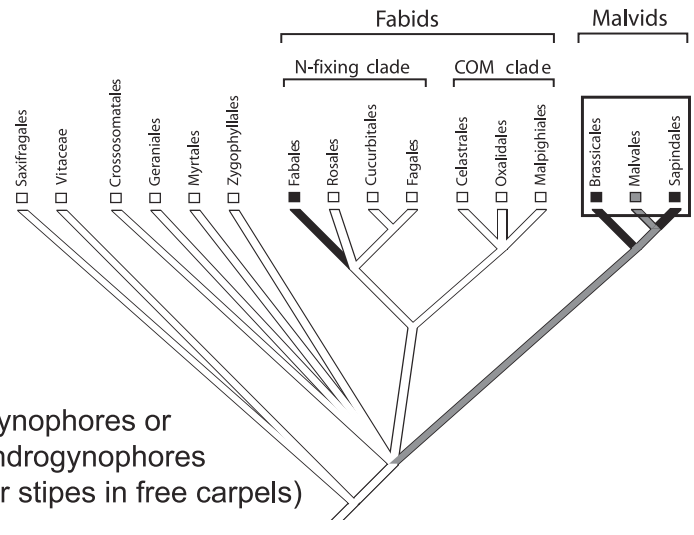

5

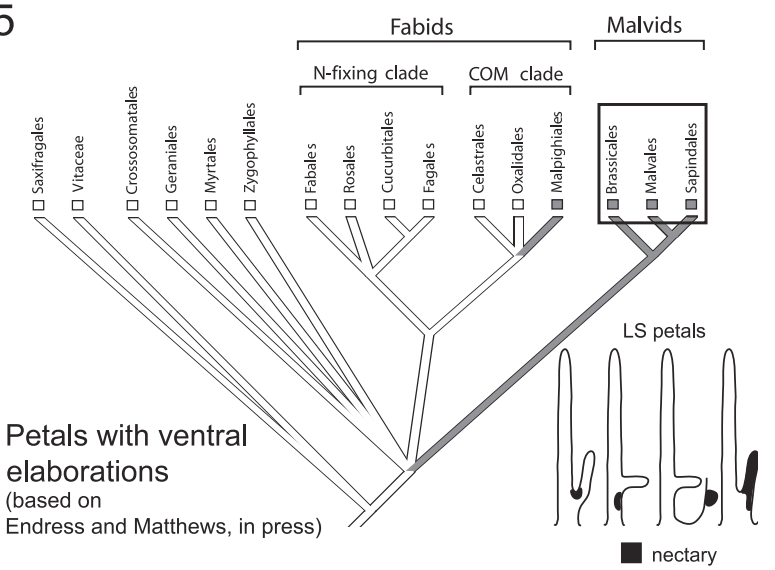

7

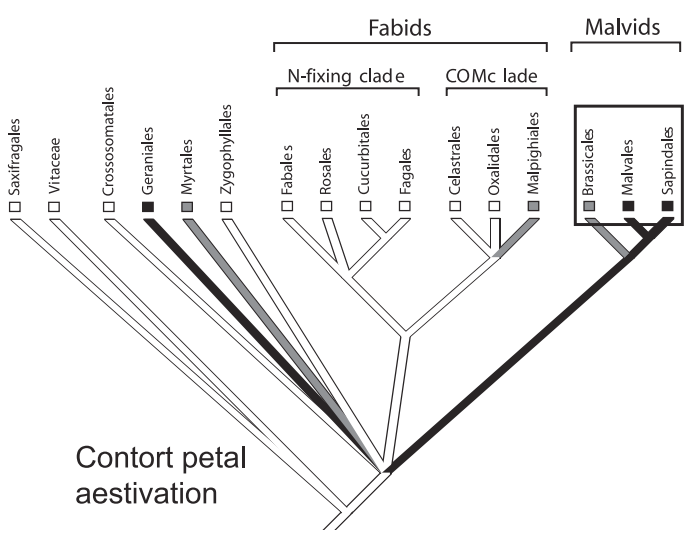

Figs. 2-7. Presence of features that are concentrated in malvids among rosids plus potential sisters (topology modified after APG 2003 and Soltis et al. 2005; soft polytomy setting of MacClade 4.07 used for illustration). Signatures: white: absent or rare; gray: present in at least 2 families, if the order has 5 or more families (or in less than $50 \%$ of the families, in which the feature has been studied); black: present in at least $50 \%$ of the families (in which the feature has been studied) and in more than 1 genus each, if the families are not too small 
In rosids, campylotropous ovules are almost always associated with a zig-zag micropyle (Fig. 2). (Interestingly, this is not the case in the campylotropous ovules of the non-rosid Caryophyllales, in which the micropyle has no zig-zag pattern because it is commonly formed by the inner integument alone.) Both campylotropous ovules and zig-zag micropyles are concentrated in malvids (also in Fabales, and less so in Geraniales).

The frequent co-occurrence of these two patterns may be seen as a functionally linked pair of features in malvids. However, there are also cases in malvids in which the ovules have a zig-zag micropyle but are not campylotropous (e.g. Poncirus, Rutaceae, Boesewinkel 1978). The same is known from some Fabales (e.g. Fabaceae, Hardenbergia, Berg 1979; Polygalaceae, Moutabea, Verkerke 1985). This gives the impression that either the two features are not completely linked or, more interestingly, that a zig-zag micropyle, and thus, an excessive growth of the outer integument may be a precondition for the excessive ovule curvature that leads to the campylotropous form.

Campylotropous ovules are recorded in at least 8 (of the 14) families of Brassicales (Brassicaceae, Bowman 1994; Bretschneideraceae, Tobe and Peng 1990; Capparaceae, Rodionova 1983; Cleomaceae, Khan 1950; Emblingiaceae, Melville 1969; Gyrostemonaceae, Eckardt 1971; Resedaceae, Chaban and Yakovlev 1974; Tovariaceae, Mauritzon 1935; unknown in Koeberliniaceae and Pentadiplandraceae), at least 3 (of the 9) families of Malvales (Cochlospermaceae, Nandi 1998b; Malvaceae, Chandra and Bhatnagar 1976; Neuradaceae, Murbeck 1916; unknown in Diegodendraceae), and at least 4 (of the 9) families of Sapindales (Burseraceae, Narayana 1960; Rutaceae, Boesewinkel 1984; Sapindaceae, Weckerle and Rutishauser 2005; Simaroubaceae, Narayana 1957; unknown in Biebersteiniaceae and Kirkiaceae).

Similarly, zig-zag micropyles were recorded in at least 7 families of Brassicales (Brassicaceae, Belyaeva and Fursa 1981; Bretschneider- aceae, Tobe and Peng 1990; Capparaceae, Rodionova 1983; Cleomaceae, Maheshwari and Khan 1953; Moringaceae, Puri 1941; Resedaceae, Singh and Gupta 1968; Tovariaceae, Mauritzon 1935), 5 families of Malvales (including 7 subfamilies of Malvaceae) (Bixaceae, Nandi 1998b; Cochlospermaceae, Schnarf 1931a; Malvaceae, Rao 1954; Muntingiaceae, Rao 1952; Thymelaeaceae, Guérin 1916), and 3 families of Sapindales (Meliaceae, Prakash et al. 1977; Rutaceae, Starshova and Solntseva 1973; Sapindaceae, Weckerle and Rutishauser 2003).

Developmentally retarded inner integument. There are ovules in which the inner integument is developmentally retarded in comparison to the outer integument and nucellus. In such ovules the inner integument is much shorter than the outer and may not even be long enough to take part in micropyle formation in the mature ovule. The tendency to form such ovules is present predominantly in the malvids. It is reported in Brassicales in at least 4 families (Akaniaceae, Tobe and Raven 1995; Brassicaceae, Sumner and Van Caesele 1988; Capparaceae, Narayana 1962; Cleomaceae, Arunalakshmi 1989), among Malvales in 6 subfamilies of Malvaceae (e.g. Rao 1949) and among Sapindales in Rutaceae (Boesewinkel 1977) and Meliaceae (Paetow 1931).

This feature may also be developmentally/ functionally connected with campylotropy and excessive growth of the outer integument. Such a connection may be supported by the additional occurrence of a delayed inner integument in a number of Fabaceae (Dnyansagar 1958), in which campylotropy and zig-zag micropyle are also common.

Gynophores or androgynophores (or stipes in free carpels) (Fig. 3). A gynophore is a stalk-like part (or at least a constriction) between the ovary and the next outer floral organs, in bisexual flowers, the androecium. In apocarpous gynoecia, each carpel may have a stalk-like base, which is called a stipe. An androgynophore is a stalk-like organ between the androecium and the next outer floral organs, in flowers with petals, the corolla. 
Gynophores (or stipes) and androgynophores are concentrated in malvids. In Brassicales they are recorded in at least 8 families (Brassicaceae, Endress 1992; Capparaceae, Endress 1992; Cleomaceae, Endress 1992; Moringaceae, Periasamy and Indira 1986; Pentadiplandraceae, Ronse De Craene 2002; Resedaceae, Sobick 1983; Salvadoraceae, Khsetrapal 1970; Setchellanthaceae, Tobe et al. 1999), in Malvales in at least 3 families (Malvaceae, Correll and Correll 1982; Sphaerosepalaceae, Horn 2004; Thymelaeaceae, Venkateswarlu 1947), and in Sapindales in at least 4 families (Burseraceae, Engler 1931a; Meliaceae, Harms 1940; Rutaceae, Engler 1931b; Simaroubaceae, Endress et al. 1983).

Another clade in which these features are concentrated are Fabales in fabids (Fabaceae, Lewis et al. 2005; Polygalaceae, Leinfellner 1972; Surianaceae, Gutzwiller 1961).

Gynoecium with more than five carpels in a whorl (Fig. 4). The tendency to form gynoecia with more than five carpels in a whorl is prominent in malvids. In Brassicales it is recorded in at least 3 families (Capparaceae, Ronse De Craene and Smets 1997; Gyrostemonaceae, Hufford 1996; Tovariaceae, Fisel and Weberling 1990), in Malvales in at least 3 families (Cytinaceae, Igersheim and Endress 1998; Malvaceae, Correll and Correll 1982; Neuradaceae, Ronse De Craene and Smets 1995), and in Sapindales also in at least 3 families (Anacardiaceae, pers. obs.; Meliaceae, Narayana 1959; Rutaceae, Engler 1931b).

Another clade with a certain concentration of taxa with more than 5 carpels in a whorl are Malpighiales of the COM clade of fabids. This feature is present in at least 11 (out of 37) families (Achariaceae, Gilg 1925; Caryocaraceae, Dickison 1990a; Clusiaceae, Engler 1925; Euphorbiaceae, Webster 1994; Medusagynaceae, Dickison 1990b; Ochnaceae, Rao and Gupte 1957; Phyllanthaceae, Sutter 1994; Djarwaninshih 2004; Quiinaceae, Schneider et al. 2002; Rafflesiaceae, Igersheim and Endress 1998; Rhizophoraceae, Setoguchi et al. 1996; Salicaceae, van Heel 1967).
Petals with ventral elaborations (Fig. 5). Petals with ventral elaborations are mostly associated with a nectary (Endress and Matthews 2006). They can be related to peltate carpel form and may be expressed as a ventral scale. They can also be more complicated, exhibiting more than one scale either side by side or one behind the other. The nectary can be above or below the ventral scale (or one of the ventral scales), or make up the entire scale, or be on another organ next to the scale (Fig. 5).

Such petals tend to be concentrated in malvids. They were reported in Brassicales in at least 5 families (Cleomaceae, Emblingiaceae, Pentadiplandraceae, Resedaceae, and Tropaeolaceae), in Malvales at least in the family Malvaceae (in 4 subfamilies), and in Sapindales in at least 2 families (Anacardiaceae, Sapindaceae) (Endress and Matthews 2006).

They are also reported in at least 6 families of Malpighiales (Achariaceae, Dichapetalaceae, Erythroxylaceae, Hypericaceae, Linaceae, Turneraceae) (Endress and Matthews 2006).

Monosymmetric flowers (Fig. 6). The tendency to form monosymmetric flowers is conspicuous in malvids. They are reported in Brassicales in at least 8 families (Brassicaceae, Rollins 1963; Bretschneideraceae, Ronse De Craene et al. 2002; Capparaceae, Vogel 1954; Cleomaceae, Endress 1992; Emblingiaceae, Leins 1969; Moringaceae, Olson 2003; Resedaceae, Sobick 1983; Tropaeolaceae, Ronse De Craene and Smets 2001), in Malvales in at least 2 families (Cochlospermaceae, Poppendieck 1980; Malvaceae, Fryxell 1983), and in Sapindales in at least 4 families (Anacardiaceae (monosymmetry by reduction), Mitchell and Mori 1987; Rutaceae, Engler 1931b; Sapindaceae, Ronse De Craene et al. 2000; Meliaceae, Harms 1940).

In addition, in several malvids, monosymmetry may be oblique, i.e. the symmetry plane is not the median plane that is formed by the axillant axis and the subtending leaf (pherophyll) of the flower. This was reported for certain Brassicales (Bretschneideraceae, Ronse De 
Craene et al. 2002; Moringaceae, Olson 2003; Tropaeolaceae, Ronse De Craene and Smets 2001) and Sapindales (Rutaceae, Engler 1931b; Sapindaceae, Ronse De Craene et al. 2000).

Monosymmetric flowers in eurosids are also concentrated in Fabales (Fabaceae, Polygalaceae) and, to some extent, in Malpighiales (Chrysobalanaceae, Prance and White 1988; Dichapetalaceae, Engler and Krause 1931; Euphorbiaceae, Radcliffe-Smith 2001; Euphroniaceae, Lleras 1976; Lacistemaceae (monosymmetry by reduction), Endress 1999; Malpighiaceae, Vogel 1990; Ochnaceae, Amaral 1991; Passifloraceae, Sazima and Sazima 1978; Podostemaceae, Razi 1955; Trigoniaceae, Kopka and Weberling 1984). However, among Malpighiales, in most families in which monosymmetric flowers occur, they are rare.

Outside of eurosids (fabids and malvids) there are concentrations of monosymmetric flowers in Geraniales (Geraniaceae, Melianthaceae) and Myrtales (Lythraceae, Melastomataceae, Myrtaceae, Onagraceae, Vochysiaceae).

Contort petal aestivation (Fig. 7). Contort petal aestivation tends to be concentrated in malvids. It is reported from at least 6 families in Brassicales (Akaniaceae, Ronse De Craene et al. 2002; Capparaceae, Ronse De Craene et al. 2002; Caricaceae, Ronse De Craene and Smets 1999; Koeberliniaceae, Mehta and Moseley 1981; Limnanthaceae, Eichler 1878; Moringaceae, Olson 2003), at least 6 families in Malvales (Cistaceae, Nandi 1998a; Cochlospermaceae, Poppendieck 1980; Dipterocarpaceae, Rao 1962; Malvaceae, Bayer and Kubitzki 2002; Neuradaceae, Huber 1993; Sarcolaenaceae, Bayer 2002), and at least 6 families in Sapindales (Burseraceae Lam 1932; Meliaceae, Murty and Gupta 1978; Peganaceae, Ronse De Craene and Smets 1996; Rutaceae, Correll and Correll 1982; Sapindaceae, Ronse De Craene et al. 2002; Simaroubaceae, Correll and Correll 1982).

A second centre of occurrence is in Malpighiales, where it is reported from at least 10 families (Bonnetiaceae, Maguire 1972; Clusiaceae, Gill et al. 1998; Ctenolophonaceae, Narayana and Rao 1971; Euphorbiaceae, En- dress 1999; Humiriaceae, Narayana and Rao 1969; Ixonanthaceae, Steyermark and Luteyn 1980; Linaceae, Endress 1999; Medusagynaceae, Dickison 1990b; Ochnaceae, Amaral 1991; Turneraceae, Gonzalez 1993).

Outside of eurosids it is also present in Geraniales (Geraniaceae, Hypseocharitaceae, Ledocarpaceae) and Myrtales (Combretaceae, Lythraceae, Melastomataceae, Onagraceae).

\section{Fabids (= eurosids I)}

A feature of apparent concentration in fabids that needs further exploration is idioblasts with a conspicuously thickened, mucilaginous periclinal internal cell wall on the outer sepal surface (Matthews and Endress, submitted). Anatropous ovules (as opposed to campylotropous in malvids) are predominant in fabids (except for some Fabales). However, anatropous ovules are also predominant in noneurosid rosids and are likely plesiomorphic in rosids. It appears easier to find synapomorphies for the two major subclades of the fabids than for the fabids as a whole.

\section{COM Clade}

Relatively thin nucellus and presence of an integumentary endothelium (Figs. 8, 9). Most prominent in the COM clade is ovule structure with respect to nucellus thickness and endothelium formation. However, the diversity of form found in the nucellus is not sufficiently captured by the commonly used terminology. The two classically distinguished nucellus types, crassinucellar and tenuinucellar, are defined by the location of the meiocyte and resulting megaspores. In a crassinucellus, the meiocyte and megaspores are deeply buried under several cell layers. In a tenuinucellus, the meiocyte and megaspores are situated immediately below the epidermis and fill the entire nucellus (apart from the epidermis). However, there are also two intermediate forms, which deserve distinction, weakly crassinucellar, with a subepidermal cell or cell layer covering the meiocyte and megaspores, and incompletely 

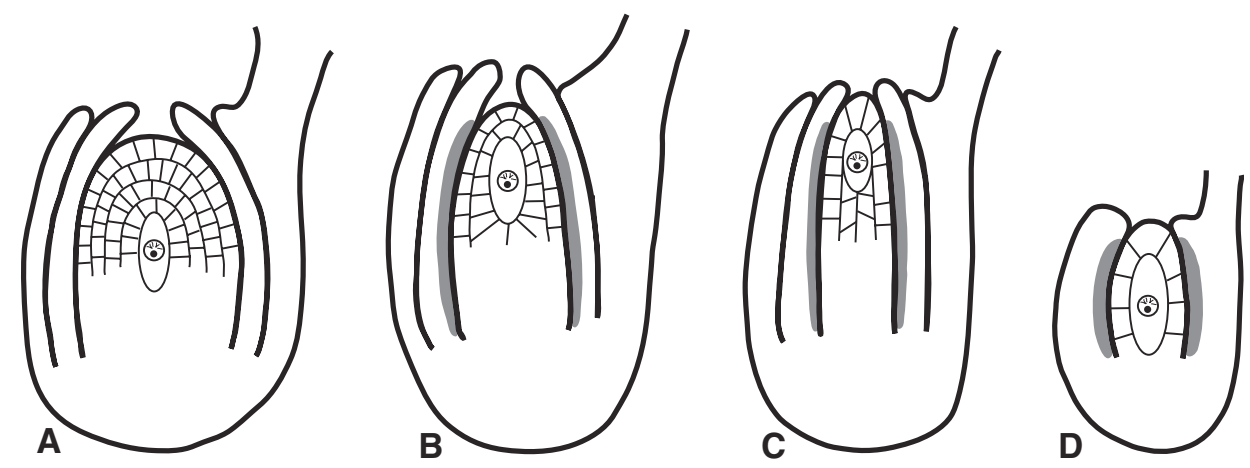

Fig. 8. Types of ovules (schematic median longitudinal sections at meiocyte stage; shaded: integumentary endothelium). A Crassinucellar. B Weakly crassinucellar. C Incompletely tenuinucellar. D Tenuinucellar

tenuinucellar, with the meiocyte and megaspores subepidermal but not filling the entire nucellus (Endress 2003). Tenuinucellar ovules and the two intermediate types tend to have an endothelium, i.e. a secretory tissue in the integument epidermis adjacent to the nucellus. During embryo sac formation the thin nucellus is dissolved by the growing embryo sac, and the embryo sac becomes contiguous with this endothelium.

Thin nucelli plus an endothelium are a good character for the COM clade. Weakly crassinucellar or incompletely tenuinucellar ovules are reported in Celastrales from 2 (of the 3) families (Celastraceae, Matthews and Endress 2005b; Parnassiaceae, Matthews and Endress 2005b), in Malpighiales from at least 19 (of the 37) families (Balanopaceae, Merino Sutter and Endress 2003; Bonnetiaceae, Prakash and Lau 1976; Chrysobalanaceae, Tobe and Raven 1984; Clusiaceae, Puri 1939 (endothelium not mentioned); Dichapetalaceae, Boesewinkel and Bouman 1980; Elatinaceae, Dathan and Singh 1971; Erythroxylaceae, Boesewinkel and Geenen 1980; Humiriaceae, Boesewinkel 1985; Hypericaceae, Rao 1957; Ixonanthaceae, Rao and Narayana 1955; Linaceae, Boesewinkel 1980; Lophopyxidaceae, Sleumer 1942; Ochnaceae, Narayana 1973; Pandaceae Takhtajan 1997; Podostemaceae, Murguía-Sánchez et al. 2002; Putranjivaceae, Singh 1970; Rafflesiaceae, Igersheim and Endress 1998; Rhizophoraceae, Tobe and Raven 1988b; Trigoniaceae, Boesewinkel 1987), and in Oxalidales from at least 3 (of the 6) families (Cephalotaceae, Cunoniaceae, Oxalidaceae, Matthews and Endress 2002).

In addition, it is of special interest that in the COM clade even in crassinucellar ovules the nucellus tends to be relatively narrow (Matthews and Endress 2002, 2005b). And even in such crassinucellar ovules of the COM clade, an endothelium may also be present, a combination which is rare in other rosids. This combination is reported in Celastrales from Celastraceae (Adatia and Gavde 1962), in Malpighiales from at least 5 families (Erythroxylaceae, Mametyeva 1985; Ixonanthaceae, Narayana 1970; Linaceae, Narayana 1963; Putranjivaceae, Tokuoka and Tobe 1999; Rhizophoraceae, Nikiticheva and Yakovlev 1985), and in Oxalidales from at least 4 families (Oxalidaceae, Boesewinkel 1985; Connaraceae, Mauritzon 1939; Cunoniaceae, Mauritzon 1939; Elaocarpaceae, including Tremandraceae, Matthews and Endress 2002). Also in Zygophyllaceae, which may be sister of fabids (but with less than $50 \%$ support, Soltis et al. 2005), crassinucellar or weakly crassinucellar ovules combined with an endothelium are present (Phatak 1971).

Seeds with arils (Fig. 10). Seeds with arils are also conspicuous for the COM clade. They are reported in Celastrales from 2 families (Celastraceae, Kapil et al. 1980; Lepidobotryaceae, Hammel and Zamora 1992), in Malpighiales from at least 13 families (Achariaceae, Steyn et al. 2002; Clusiaceae, Corner 
1976; Ctenolophonaceae, Takhtajan 1997; Euphorbiaceae, Tokuoka and Tobe 2002, 2003; Ixonanthaceae, Winkler 1931; Malesherbiaceae, Harms 1925; Passifloraceae, Kloos and Bouman 1980; Phyllanthaceae, pers. obs., Picrodendraceae, Berg 1975; Rhizophoraceae, Tobe and Raven 1987b; 1988b; Salicaceae, van Heel 1979; Turneraceae, Kloos and Bouman 1980; Violaceae, Kapil et al. 1980), and in Oxalidales from at least 3 families (Connaraceae, Corner 1976; Elaeocarpaceae, including Tremandraceae, Boesewinkel 1999; Matthews and Endress 2002; Oxalidaceae, Corner 1976).
Arils are also present but less prominent in some other clades. In malvids they are reported in Brassicales (Caricaceae, Corner 1976; Cleomaceae, Kers 1970; Setchellanthaceae, Iltis 1999), Malvales (Malvaceae, Corner 1964), and Sapindales (Meliaceae, Corner 1976; Sapindaceae, van der Pijl 1957, Weckerle and Rutishauser 2005). In Fabales they are reported from a number of Fabaceae and Polygalaceae. In Crossosomatales they occur in Crossosomataceae, Stachyuraceae, and in reduced form, in Ixerbaceae and Strasburgeriaceae (Matthews and Endress 2005a).
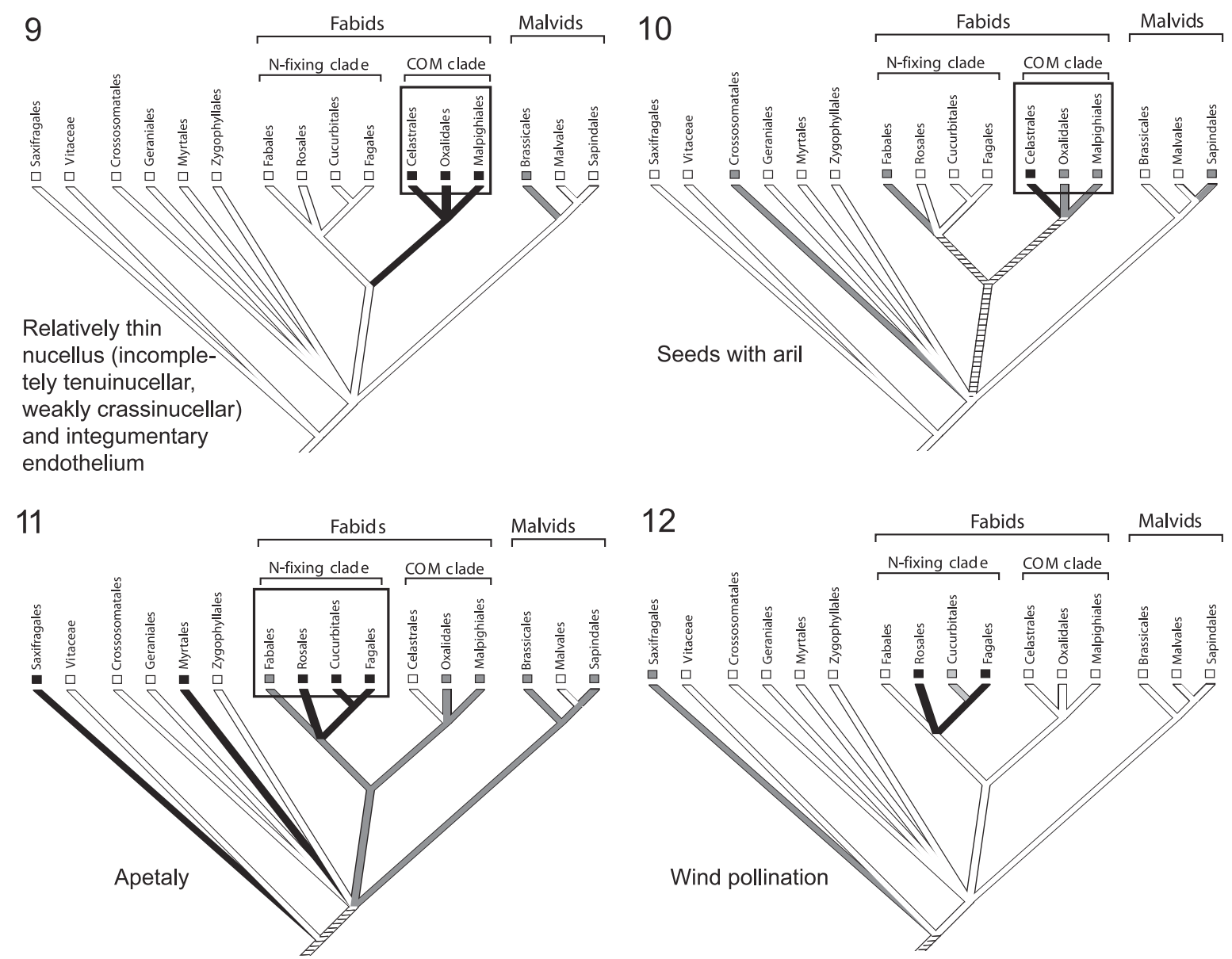

Figs. 9-12. Presence of features that are concentrated in fabids among rosids and potential sisters (topology modified after APG 2003 and Soltis et al. 2005; soft polytomy setting of MacClade 4.07 used for illustration). Signatures: white: absent or rare; gray: present in at least 2 families if the order has 5 or more families (or in less than $50 \%$ of the families, in which the feature has been studied); black: present in at least $50 \%$ of the families (in which the feature has been studied) and in more than 1 genus each, if the families are not too small 
Nitrogen-fixing clade

Outer integument thicker than inner integument. In the nitrogen-fixing clade the outer integument is commonly thicker than the inner. However, this is also the case in putative sister groups of rosids, such as Saxifragales and Vitaceae. Thus it may be plesiomorphic for rosids (see below).

Unitegmic ovules. There is a tendency towards unitegmic ovules in the nitrogen-fixing clade, which are otherwise very rare in rosids. Unitegmic ovules are reported in Cucurbitales from Anisophylleaceae (Tobe and Raven 1987a), in Fabales from 2 (of the 4) families (Fabaceae (only Lupinus), Atabekova 1963, Surianaceae, Heo and Tobe 1994), in Fagales from 5 (of the 8) families (Nothofagaceae, Poole 1952; Betulaceae, Endress 1967, Sogo and Tobe 2005; Juglandaceae, Verhoog 1968; Myricaceae, Macdonald and Sattler 1973; Ticodendraceae, Tobe 1991), and in Rosales in 1 (of the 9) families (Rosaceae, Juel 1918).

In contrast, in the COM clade unitegmic ovules are unknown from Celastrales and Oxalidales, and are only reported from few Malpighiales (Caryocaraceae, Dickison 1990a; Clusiaceae, Treub 1911; Salicaceae, Steyn et al. 2004).

In malvids, unitegmic ovules are unknown from Malvales. In Brassicales, they are only known from Limnanthaceae, and in Sapindales only from very few Anacardiaceae (Copeland 1955; Bachelier and Endress, unpubl. data), Burseraceae (Wiger 1935), Meliaceae (Wiger 1935), and Rutaceae (Boesewinkel and Bouman 1978).

Apetaly (Fig. 11). There is also a tendency towards apetaly in the nitrogen-fixing clade. In Cucurbitales, apetaly is present at least in part in 4 (of the 7) families (Anisophylleaceae, Begoniaceae, Datiscaceae, Tetramelaceae, Matthews and Endress 2004), in all Fagales, in Fabales in a few Fabaceae (e.g. Tucker 1992) and in Stylobasium of Surianaceae (Carlquist 1978), and at least in part, in 7 (of the 9) families of Rosales (Barbeyaceae, Cannabaceae, Elaeagnaceae, Rao 1974; Moraceae,
Rhamnaceae, Tomlinson 1980; Rosaceae, Fellingham and Linder 2003; Ulmaceae, Urticaceae).

In all other large clades of fabids, the incidence of apetaly is much more rare. In Celastrales apetaly appears to be absent, and in Malpighiales it is known from 9 families (Achariaceae, Gilg 1925; Balanopaceae, Merino Sutter and Endress 2003; Chrysobalanaceae, Prance and White 1988; Euphorbiaceae, Webster 1994; Lacistemaceae, Agostini 1973; Phyllanthaceae, Webster 1994; Picrodendraceae, Merino Sutter et al., 2006; Putranjivaceae, Webster 1994; Salicaceae, Gilg 1925). In Oxalidales it is reported from 4 families (Brunelliaceae, Cuatrecasas 1970; Cephalotaceae, Matthews and Endress 2002; Cunoniaceae, Moody and Hufford 2000, Matthews et al. 2001; Elaeocarpaceae, only part of Sloanea, Coode 2004, Endress and Matthews, in press).

Also in malvids apetaly is uncommon: in Brassicales it is reported from 2 families (Capparaceae, Pax and Hoffmann 1936; Gyrostemonaceae, Hufford 1996), in Malvales it is only present in part of Thymelaeaceae (Domke 1934) and some cleistogamous flowers of Cistaceae and Malvaceae, and in Sapindales it is reported from a few Anacardiaceae and Sapindaceae (Leenhouts 1978).

Outside of eurosids, there are two centres of apetaly. One is in Myrtales, in which it is reported from at least 7 (of 14) families (Alzateaceae, Dahlgren and Thorne 1984; Combretaceae, Correll and Correll 1982; Crypteroniaceae, Takhtajan 1997; Lythraceae, Koehne 1903; Myrtaceae (although petal primordia are present), Bohte and Drinnan 2005; Onagraceae, Berry et al. 2004; Penaeaceae, Schönenberger and Conti 2003). The other centre is in Saxifragales, in which it is reported from 10 (of 16) families (Altingiaceae, Wisniewski and Bogle 1982; Aphanopetalaceae, Dickison et al. 1994; Cercidiphyllaceae, Endress 1986; Cynomoriaceae, Steindl 1945; Daphniphyllaceae, Endress and Igersheim 1999; Haloragaceae, Orchard 1975; Hamamelidaceae, Endress 1970, 1978; Penthoraceae, 
Engler 1930; Peridiscaceae, Gilg 1925; Saxifragaceae, Engler 1930).

Wind pollination (Fig. 12). Similarly there is a tendency towards wind pollination in the nitrogen-fixing clade, which is functionally linked with apetaly. It is present in Cucurbitales in Coriariaceae, Datiscaceae, and, perhaps, Tetramelaceae (Matthews and Endress 2004), in all families of Fagales, among Fabales in Surianaceae (Stylobasium) (Carlquist 1978), and in Rosales, at least in part, in Barbeyaceae, Cannabaceae, Elaeagnaceae, Moraceae, Rosaceae, Ulmaceae, and Urticaceae (Berg 1989, Fellingham and Linder 2003). Interestingly, most actinorrhizal genera out of the 3 orders that have actinorrhiza, are windpollinated (all respective genera in Fagales and Cucurbitales, Hippophae in Elaeagnaceae, and Cercocarpus in Rosaceae).

In the COM clade and in malvids, wind pollination appears to be very rare. A systematic centre of occurrence of wind pollination outside of eurosids are again Saxifragales, in which wind pollination is reported from Altingiaceae (Endress 1977), Cercidiphyllaceae (Endress 1986), Daphniphyllaceae (probably wind-pollinated, but unstudied in this respect), Haloragaceae (Orchard 1975), and some Hamamelidaceae (Endress 1977).

Carpels or gynoecia with a single ovule. Another trend that is functionally linked with wind pollination is the presence of only a single ovule per carpel or gynoecium in many groups of the nitrogen-fixing clade. This feature occurs in at least 4 families of Cucurbitales (Anisophylleaceae, Tobe and Raven 1988a, Matthews et al. 2001; Coriariaceae, Matthews and Endress 2004; Corynocarpaceae, Matthews and Endress 2004; rarely in Cucurbitaceae, Matthews and Endress 2004), at least 4 families of Fagales (Betulaceae, Sogo and Tobe 2005; Juglandaceae, Verhoog 1968; Myricaceae, Kershaw 1909; Rhoipteleaceae, Zhang et al. 1994), at least 3 families of Fabales (Fabaceae, Joshi 1938; Polygalaceae, Leinfellner 1972; Surianaceae, Carlquist 1978), and most families of Rosales (Barbeyaceae, Ronse De Craene and Miller
2004; Cannabaceae, Eckardt 1937; Dirachmaceae, Ronse De Craene and Miller 2004; Elaeagnaceae, Ronse De Craene and Miller 2004; Moraceae, Yamazaki 1982; Rhamnaceae, Laguna and Cocucci 1971; Rosaceae, Juel 1918; Ulmaceae, Shattuck 1905; Urticaceae, Fagerlind 1944). In other clades of eurosids the feature is less prominent.

Vascular bundle(s) in integument(s). A tendency towards the presence of vascular bundles in integuments is relatively prominent in the nitrogen-fixing clade. In Cucurbitales it is recorded in the outer integument of at least 3 families (Corynocarpaceae, Cucurbitaceae) and in the single integument in Anisophylleaceae (Matthews and Endress 2005), in Fagales in at least 6 families in the single or outer integument (Betulaceae, Endress 1967; Casuarinaceae, Flores and Moseley 1982; Fagaceae, Fey 1981; Juglandaceae, Nast 1935; Myricaceae, Kershaw 1909; Ticodendraceae, Tobe 1991), in Fabales in the outer integument in Fabaceae (but only after anthesis) (Dnyansagar 1958), and in Rosales in the outer integument of Rhamnaceae (Laguna and Cocucci 1971).

Among the COM clade the presence of vascular bundles in integuments is less prominent. In Oxalidales it appears to be absent. In Celastrales it is recorded from Celastraceae in the outer integument (only Stackhousia) (Matthews and Endress 2005b). In Malpighiales it is reported from 6 families (Achariaceae, Steyn et al. 2002; Euphorbiaceae, Tokuoka and Tobe 1995, 2002, 2003; Phyllanthaceae, Tokuoka and Tobe 2001), Putranjivaceae, Tokuoka and Tobe 1999; Salicaceae, Dathan and Singh 1979; Rhizophoraceae, Nikiticheva and Yakovlev 1985).

In malvids, integumentary vascular bundles are only present in some small families of Brassicales in the outer (or single) integument (Akaniaceae, Tobe and Raven 1995; Bretschneideraceae, Tobe and Peng 1990; Limnanthaceae, Stenar 1925; Moringaceae, Puri 1942), in Malvales in Dipterocarpaceae (Rao 1955) and Malvaceae (Rao 1954), and in Sapindales in some Anacardiaceae and 
Sapindaceae (but apparently only after anthesis) (Corner 1976).

\section{Cucurbitales plus Fagales}

The sister orders Cucurbitales and Fagales tend to have trimerous, unisexual flowers and an inferior ovary, and most Fagales and at least 2 (of the 7) families of Cucurbitales are wind-pollinated (Crane and Blackmore 1989; Matthews and Endress 2004). However, based on the occurrence of bisexual Cretaceous fagalean fossil flowers (Friis 1983; Sims et al. 1998, 1999) and phylogenetic analyses of extant Fagales, unisexual flowers and wind pollination may not be synapomorphic in the clade (Manos et al. 2001). However, most of the well preserved Upper Cretaceous fossil flowers of Fagales appear to be unisexual (Friis and Crane 1989; Herendeen et al. 1995 1999; Schönenberger et al. 2001; Friis et al. 2003, 2006), which indicates that it is an old feature. Although Cucurbitales flowers are not known in the fossil record (Crepet et al. 2004), the complete unisexuality in Begoniaceae, Cucurbitaceae, Datiscaceae, and Tetramelaceae is an indirect indicator of it being an old feature.

\section{Malvales plus Sapindales}

The sister orders Malvales and Sapindales have a tendency towards the presence of several (more than two) meiocytes in an ovule and elaborate apocarpy. The regular occurrence of several meiocytes in an ovule has been reported in Malvales in Cistaceae (e.g. Kapil and Maheshwari 1964) and in 4 subfamilies of Malvaceae (e.g. Kamalova et al. 1983), and in Sapindales in Burseraceae (Shukla 1954), Meliaceae (Prakash et al. 1977), Simaroubaceae (Nair and Joseph 1957), and Sapindaceae (Alimova 1985b). Other centres of occurrence for this feature in eurosids are Fagales (Betulaceae, Zhang and Chen 1993; Casuarinaceae, Sogo et al. 2004; and Fagaceae, Hjelmqvist 1953), and Rosales (Rhamnaceae, Arora 1953; and Rosaceae, Hjelmqvist 1956). Outside of eurosids and rosids, Saxifragales should be mentioned (Aphanopetalaceae, Mauritzon 1939; Crassulaceae, Mauritzon 1930; Hamamelidaceae, Endress 1977; and Paeoniaceae, Murgai 1962).

Elaborate apocarpy is here defined as free carpels in which the upper part is postgenitally united at anthesis. This postgenital bond allows the formation of a compitum, a centralized pollen tube transmitting tract, in which centralized pollen tube selection can take place (Endress 1982, Endress et al. 1983, Armbruster et al. 2002). Within eurosids such elaborate apocarpy seems to be restricted to some Malvales and Sapindales. In Malvales it is known from Malvaceae-Sterculioideae (Endress et al. 1983, Jenny 1988), and in Sapindales it is present in many Rutaceae and Simaroubaceae (Endress et al. 1983, Ramp 1988). Among non-eurosid rosids it is known from some Crossosomatales (although with some basal syncarpy; Staphyleaceae, Ramp 1987; Geissolomataceae, Ixerbaceae, Matthews and Endress 2005a), and outside rosids, in Saxifragales (Iteaceae, Hermsen et al. 2003).

\section{Potential relationships between larger clades not shown in molecular studies: Malvids plus COM clade}

Inner integument thicker than outer (Fig. 13). An especially interesting feature is an inner integument that is thicker than the outer at the time of fertilization. It dominates in both malvids and the COM clade of fabids, but is rare in other rosid orders. This feature must be determined at comparable developmental stages in these clades, because the thickness ratio of the two integuments may change during development. Both integuments may be two-cell-layered in the beginning but the inner may become thicker up to anthesis (Hakki 1974, Boesewinkel 1987).

In malvids this feature is present in Brassicales, in at least 6 families (Brassicaceae, Haughn and Chaudhury 2005; Capparaceae, Rodionova 1983; Caricaceae, Stephens 1910; Cleomaceae, Arunalakshmi 1989; Resedaceae, 


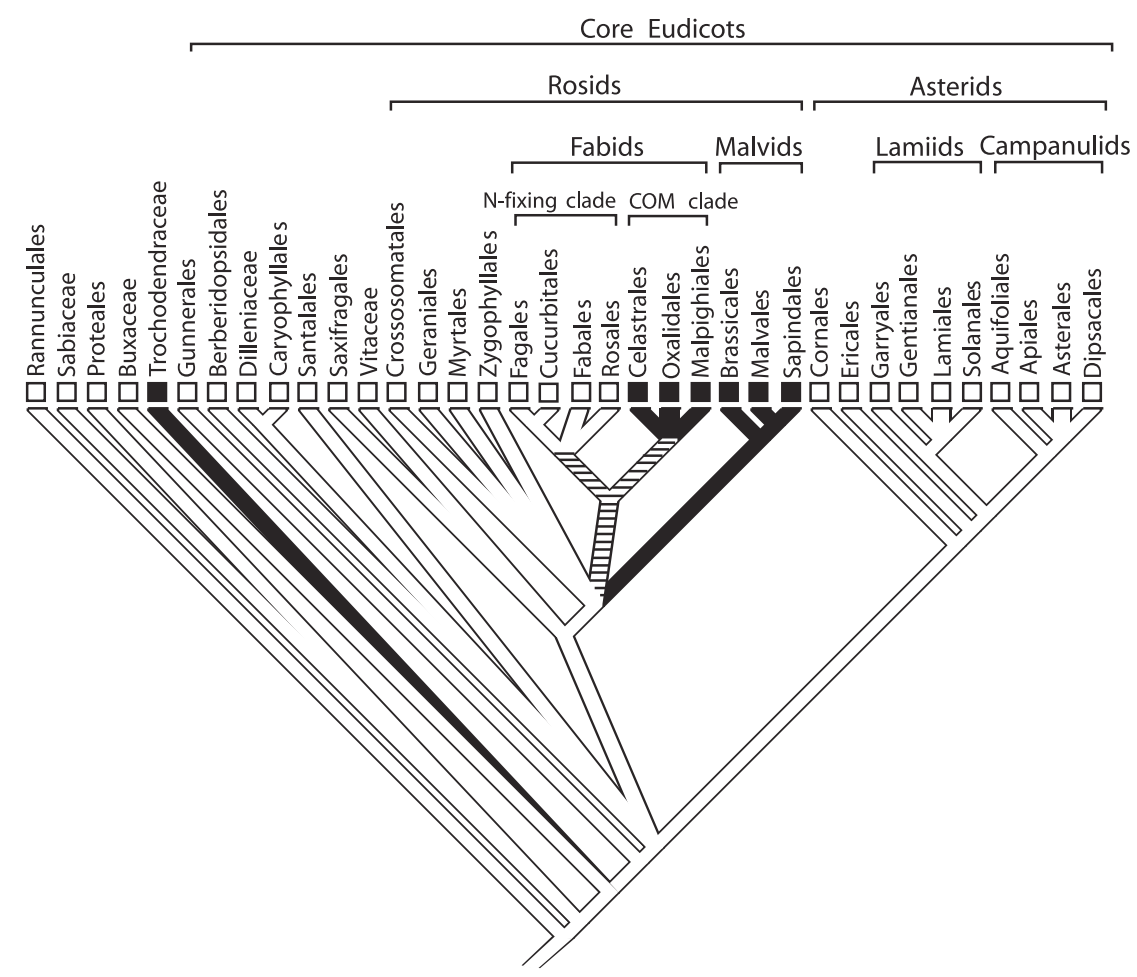

Fig. 13. Presence of an inner integument that is thicker than the outer in eudicots (topology modified after APG 2003 and Soltis et al. 2005; soft polytomy setting of MacClade 4.07 used for illustration). Signatures as in Fig. 9

Singh and Gupta 1968; Tovariaceae, Mauritzon 1935; 6 families, Bataceae, Emblingiaceae, Gyrostemonaceae, Koeberliniaceae, Pentadiplandraceae, Setchellanthaceae, are unstudied in this respect, and for Limnanthaceae the feature is not applicable because the ovules are unitegmic), in Malvales in 9 families (Apodanthaceae, Endriss 1902; Bixaceae, Mauritzon 1936; Cistaceae, Kapil and Maheshwari 1964; Cytinaceae, Bernard 1903; Dipterocarpaceae, Kaur et al. 1986; Malvaceae, Rao 1954; Muntingiaceae, Rao 1952; Neuradaceae, Murbeck 1916; Thymelaeaceae, Venkateswarlu 1947), and in Sapindales in 3 families (Meliaceae, Prakash et al. 1977; Rutaceae, Boesewinkel 1984; Simaroubaceae, Nair and Sukumaran 1960).

In the COM clade the feature is present in Celastrales, in Celastraceae and Parnassiaceae (Matthews and Endress 2005b), in Malpighiales in 16 families (Achariaceae, Steyn et al.
2002; Caryocaraceae, Dickison 1990a; Chrysobalanaceae, Tobe and Raven 1984; Dichapetalaceae, Boesewinkel and Bouman 1980; Elatinaceae, Dathan and Singh 1971; Erythroxylaceae, Boesewinkel and Geenen 1980; Euphorbiaceae, Tokuoka and Tobe 2002, 2003; Humiriaceae, Boesewinkel 1985; Phyllanthaceae, Singh 1972; Picrodendraceae, Berg 1975; Putranjivaceae, Tokuoka and Tobe 1999; Rafflesiaceae, Ernst and Schmid 1913; Rhizophoraceae, Tobe and Raven 1987b; Salicaceae, Steyn et al. 2005; Trigoniaceae, Boesewinkel 1987; Turneraceae, Kloos and Bouman 1980), and in Oxalidales in 4 families (Brunelliaceae, Cephalotaceae, Cunoniaceae, Elaeocarpaceae, incl. Tremandraceae, Matthews and Endress 2002).

In the seed this feature corresponds to the predominant differentation of the mechanical tissues in the inner integument (exo- and endotegmic seeds, as opposed to exotestal, 
mesotestal and endotestal seeds, in the terminology of Corner 1976).

Other features. There are also other features that tend to be present in malvids and Malpighiales of the COM clade but are less common in the other two orders of the COM clade. These features include (1) contort petals (see also above); (2) a tendency towards polystemony ( 15 or more stamens in a flower): in at least 18 families of Malpighiales (Achariaceae, Bonnetiaceae, Caryocaraceae, Chrysobalanacae, Clusiaceae, Euphorbiaceae, Humiriaceae, Hypericaceae, Medusagynaceae, Ochnaceae, Pandaceae, Passifloraceae, Phyllanthaceae, Picrodendraceae, Putranjivaceae, Quiinaceae, Rhizophoraceae, Salicaceae), 5 families in Brassicales (Capparaceae, Cleomaceae, Gyrostemonaceae, Resedaceae, Setchellanthaceae), 5 in Malvales (Bixaceae, Cistaceae, Cochlospermaceae, Malvaceae, Sarcolaenaceae), and 3 in Sapindales (Anacardiaceae, Rutaceae, Sapindaceae); (3) a tendency towards polycarpelly (more than 5 carpels in a whorl) (see also above); (4) integuments tend to be free from each other and from the nucellus. This feature was mentioned as a side observation in a number of publications and was sometimes only illustrated without any mention; however, it was never focused upon (see, e.g. Sutter and Endress 1995; Merino Sutter et al., 2006).

\section{Discussion}

\section{Promising features of potential interest at various higher levels (order and above)}

Ovule structure. Ovules have yielded especially interesting floral features in this study. Recently, attempts have been made (1) to find previously unrecognized features in ovules and (2) to redefine the classification of ovules (e.g. Shamrov 1999, Batygina 2002). However, these two goals require that further studies are carried out in a phylogenetic framework, and that both are explored for their potential significance at different systematic levels (see also Endress 2003, 2005).
Ovules with a much thicker inner than outer integument are of special interest (Fig. 13). This feature is not present in basal eudicots; only in Trochodendron and Tetracentron is the inner integument slightly thicker than the outer (Endress and Igersheim 1999). Among core eudicots outside of rosids it is absent in Gunnerales, Berberidopsidales, Caryophyllales, Santalales and asterids (van Heel 1984, Endress and Igersheim 1999), and only present in Dilleniaceae (Sastri 1958), which do not appear as the likely sister to rosids. Thus it is a clear synapomorphy for a part or parts of the rosids, especially the COM clade and malvids. There are several scenarios for the evolution of this feature. (1) It evolved once at the base of a clade consisting of the COM clade and malvids (however, such a clade is not supported by phylogenetic analyses). (2) It evolved separately twice at the base of the COM clade and the malvids. (3) It evolved separately many times in families of the COM clade and of malvids. As the feature does not occur in all families or genera of the COM clade and the malvids, there are also different scenarios to explain this pattern. (A) It evolved only once or twice (as in 1 and 2) and was lost again in a number of families or genera. (B) The tendency to form the feature was not expressed in all families or genera.

The combination of campylotropous ovules with a zig-zag micropyle is not present in basal eudicots (except for some papaveraceae). In core eudicots it occurs in Dilleniaceae, among rosids in some Geraniales and Myrtales, and among eurosids, in malvids (and some Fabales). It appears to be a separate apomorphy for each of these clades (or of parts thereof). Campylotropous ovules without a zig-zag micropyle (because only the inner integument forms the micropyle) are common in Caryophyllales. Otherwise most eudicots have anatropous ovules, and this is most probably the plesiomorphic state for rosids.

Mucilage cells. At the histological level the presence in sepals of a cell layer or single cells with a thickened, mucilaginous periclinal inner 
cell wall may be of interest. This feature seems to be new for flowers (Matthews et al. 2001, Matthews and Endress, 2006).

\section{Patterns of occurrence of interesting features}

Floral structural features of macrosystematic interest in rosids are commonly "tendential" features. They are not ubiquitous in a clade but occur much more frequently there than in related clades. The evolutionary interpretation of such tendential features is an interesting and unresolved problem in evolutionary biology. In principle there are different possibilities to assess for the presence of such a pattern: (1) The feature itself is not a synapomorphy, but only the predisposition for it to easily evolve is. (2) The feature is a synapomorphy, however, it is simply not expressed in each component of a clade, but suppressed in some. (3) The unusual concentration of a feature in a clade has arisen by coincidence, and thus represents separate autoapomorphies for each clade in which it occurs. (4) Also combinations of 1-3 are possible. Tendential features have often been addressed in evolutionary studies (e.g. Sanderson and Hufford 1996).

An example for (1) is the feature expressed in the informal name of the "nitrogen-fixing clade". Each of the four orders of this clade contains one or a few families in which nitrogen fixation by symbiontic bacteria (Frankia and Rhizobium) in the roots is present. This feature is not known from any other angiosperm group. It appears that in the common ancestor a precondition was present that allowed for the full evolution of this feature relatively easily (Soltis et al. 1995, 2005; Swensen et al. 1996). Similarly, such a situation may be assumed for other features as well. A potential example in floral structure for (1) or (2) is campylotropy of ovules in malvids, which may be seen as a further development of anatropy by a prolonged process of curvature. If the development stops earlier, anatropy does not develop into campylotropy. Thus, once the potential for campylotropy has evolved, there is higher flexibility in the expression of curvature, and both types, anatropy and campylotropy are able to develop.

Another interesting situation is where a suite of exceptional features are known to occur exclusively in very few (potentially related) groups, such as unusually structured stamens. In angiosperms stamens have a conservative organisation comprising an anther with two lateral thecae. The absence of a thecal structure in the stamens (Endress and Stumpf 1990) and presence of single pollen sacs that open individually is extremely rare in angiosperms. Among rosids it is only known from few Malvaceae (von Balthazar and Nyffeler 2002) and from Apodanthaceae (Blarer et al. 2004). As Apodanthaceae (for a long time of uncertain position, APG 2003), are at present best placed in Malvales (Nickrent et al. 2004), their unique stamen structure may help to support their position in this order. This stamen structure may be an apomorphic tendency in Malvales.

\section{Unexplored correlations of features independent of systematic position}

When surveying a number of features through a large clade, unexpected correlations between features may appear, especially in such cases in which pairs of unusual features tend to occur in combination. There are two important aspects involved in the occurrence of such correlations. (1) Why are these features correlated? (A) Are there general functional constraints that tend to always bind them together, also in distant relatives? Or (B) do these features occur associated only in certain clades but not in others? Thus, are there developmental constraints causing the features to occur together in this clade? (2) Does the presence of such a correlation in a clade constitute an especially strong systematic marker for this group? This would only be the case if (B) were correct. These questions are currently not resolvable, however we would like to present them for further consideration. 
Lobed or fringed petals and instability between presence and absence of petals (Table 1). Those orders in which lobed of fringed petals occur, also show much fluctuation between the presence and absence of petals. Additionally they often have small and narrow petals in some members, and often have valvate or united sepals (Endress and Matthews 2006). Such orders are, for example, Rosales of eurosids, Myrtales of "basal" rosids (Schönenberger and Conti 2003), and Saxifragales (Crane and Blackmore 1989, Endress 1989) outside of rosids. What is the morphogenetic or functional significance of such suites of features? This should be compared in more detail in the different groups where they occur. As a hypothesis for this correlation it may be speculated that lobed or fringed petals, if they are not in any way especially elaborate, may already exhibit a state of reduction of form.

Campylotropous ovule and zig-zag micropyle. In several larger clades campylotropous ovules are often accompanied by a zigzag micropyle. Hypothesis: the convex periphery of the ovule develops excessively and especially also the outer integument on the convex side, so that its tip grows over the micropyle. This correlation is especially prominent in malvids and Fabaceae. However, in these clades it is also of interest that in some cases only one of the two features is present, such as anatropous ovules with zig-zag micropyle, or (less often), campylotropous ovules with straight micropyle.

Retardation of inner integument and non-contiguity of integuments and nucellus. In some groups the inner integument tends to grow more slowly than the outer integument and nucellus. Hypothesis: for differential elongation non-contiguity (to avoid coherence) is necessary. If the elongation of the inner integument does not keep pace with the elongation of the outer integument and the nucellus, contiguity is not possible. This correlation is especially prominent in malvids and Malpighiales.

Thickness of integument and presence of vascular bundles. Vascular bundles are present in the seed coat in a number of angiosperm groups. In some groups one or more vascular bundles are present in one of the integuments of the ovules already at anthesis, and these integuments tend to be relatively thick. Hypothesis: if early vascular bundle formation in an integument is needed for later massive seed coat development, a certain integument thickness at anthesis is necessary. An only twocell-layered integument cannot develop vascular bundles.

Thickness of integument and its contribution to seed coat formation. The outer and the inner integument variously contribute to the mechanical layer(s) of the seed coat (testal or tegmic seed coat, Corner 1976). It appears that the integument that contributes most to the mechanical part of the seed coat is thicker than the integument that contributes least, and this already at anthesis. Hypothesis: if a massive seed coat has to be formed, the contributing integument has to have a certain thickness (see also Corner 1976).

Obturator and nucellar beak. Ovules in which a nucellar beak is present (i.e. the apex protruding out of the micropyle), also tend to have an obturator (i.e. a plug formed by an

Table 1. Correlation of tendencies in perianth differentiation within orders (based on Endress and Matthews, in press). 1. Fluctuation between presence and absence of petals; 2. Petals small and narrow; 3. Petals lobed/fringed; 4. Sepals valvate or united

\begin{tabular}{llllc}
\hline Saxifragales & 1 & 2 & 3 & $(4)$ \\
Myrtales & 1 & 2 & 3 & 4 \\
Cucurbitales & 1 & 2 & 3 & $(4)$ \\
Rosales & 1 & 2 & 3 & 4 \\
Oxalidales & 1 & 2 & 3 & 4 \\
Brassicales & 1 & 2 & $(3)$ & $(4)$ \\
\hline
\end{tabular}


adjacent part of the carpel, commonly the placenta, pointing to the micropylar region). Hypothesis: There are morphogenetic interactions between obturator and nucellus apex; an obturator tends to intrude into the micropyle and a nucellar beak tends to extrude out of the micropyle thus making contact with the obturator. One or the other part may become dominant in this interplay. This correlation was observed in Euphorbiaceae (Sutter and Endress 1995), Thymelaeaceae (Guérin 1916), Rosaceae (Sharma and Narayana 1971), and Urticaceae (Fagerlind 1944).

Presence in the ovule of several meiocytes and tubular embryo sacs. If there are several meiocytes in an ovule and several embryo sacs develop, they tend to be tubular with the largest diameter around the egg apparatus and the antipodal cells. Hypothesis: there is competition between the female gametophytes, pushing each other aside, or there is just lack of space to expand sidewards. Among rosids and relatives this is conspicuous in Crassulaceae, Sedum (Subramanyam 1968), Paeoniaceae, Paeonia (Walters 1962), and Casuarinaceae, Casuarina (Sogo et al. 2004) (see also above). This combination is also known from some other angiosperm groups.

Gynobasic style and single, tenuinucellar ovule. Gynoecia with a gynobasic style (in which the dorsal ovary region is bulged up and the style appears to be inserted at the base) tend to have a single ovule (or not more than 2 ovules) per carpel and this ovule is small, often incompletely or completely tenuinucellar. Hypothesis: A gynobasic style produces a reduction of space within the ovary locule. This combination is present among rosids in, e.g. Limnanthaceae (Maheswari and Johri 1956), Chrysobalanaceae (Juel 1915), and Ochnaceae (Chikkanaiah and Mahalingappa 1974).

Aril and crassinucellar (not tenuinucellar) ovules. Arils tend to form on crassinucellar and not on tenuinucellar ovules. Hypothesis: for the formation of an aril the ovule has to be relatively massive. This is especially well exemplified by Malpighiales, in which some families have crassinucellar ovules, while others have incompletely tenuinucellar ovules. It appears that those with arillate seeds have crassinucellar ovules. As an additional example, outside of rosids, in asterids, ovules are tenuinucellar, seeds are commonly small, and arils are not common or absent.

\section{Floral structure and systematics in rosids}

In this study we originally screened numerous features but finally focused on only a few especially informative ones that appeared relatively stable in their distribution. These features tend to be congruent with molecular results to a large degree. However, there are also some differences (Table 2).

In molecular results the deepest split within eurosids appears between the fabids (nitrogenfixing clade plus COM clade) and malvids (Soltis et al. 2000, 2005; APG 2003). However, from our floral structural results, one would rather expect the deepest split to be between the nitrogen-fixing clade and a clade of malvids plus COM clade. Although the malvids are especially well characterized, there are also special shared features between the COM clade and malvids.

It is interesting that of all apparent supraordinal clades (clusters of orders) within rosids the best supported in phylogenetic studies (Soltis et al. 2000, 2005), the malvids, are also the best supported by floral structural features. This clade also appears in the combined $r b c \mathrm{~L}$ and non-molecular analysis by Nandi et al. (1998), although with the inclusion of Myrtales.

The second major group, the fabids (Cucurbitales, Fagales, Fabales, Rosales, Celastrales, Malpighiales, Oxalidales) are less well characterized than the malvids. Among the fabids, the COM clade (Celastrales, Oxalidales, Malpighiales) appears to be best characterized by floral features.

The two sister pairs of orders within eurosids, Cucurbitales plus Fagales and Malvales plus Sapindales, both poorly supported by molecular studies, are also structurally not (yet) well characterized. 
Table 2. Degree of support by structural features of clades as compared with their molecular support (molecular support according to Soltis et al. 2000, 2005)

\begin{tabular}{lll}
\hline $\begin{array}{l}\text { Major subclades } \\
\text { of rosids } \\
\text { (above orders) }\end{array}$ & $\begin{array}{l}\text { Molecular } \\
\text { support } \\
\text { (Soltis et al. } \\
\text { 2000, 2005) }\end{array}$ & $\begin{array}{l}\text { Floral } \\
\text { structural } \\
\text { characterization }\end{array}$ \\
\hline $\begin{array}{l}\text { Malvids } \\
\text { Malvales- }\end{array}$ & ++ & ++ \\
Sapindales & & $(+)$ \\
Fabids & + & $(+)$ \\
$\begin{array}{l}\text { COM clade } \\
\text { N-fixing clade }\end{array}$ & $(+)$ & + \\
$\begin{array}{l}\text { Cucurbitales- } \\
\text { Fagales }\end{array}$ & $(+)$ & + \\
COM clade & - & ++ \\
plus malvids & & + \\
\hline
\end{tabular}

++ Strong support, + moderate support,

$(+)$ weak support,

- no support

There are a number of shared structural floral features (potential synapomorphies) indicating that the COM clade (Celastrales, Oxalidales, Malpighiales) fits better with malvids than it does with the nitrogen-fixing clade. It remains to be seen whether the weakly supported fabids gain more support by additional molecular sampling or whether the topology changes with respect to the $\mathrm{COM}$ clade plus malvids. Certainly more floral structural sampling is also badly needed.

There is still a long way to go until it will be possible to identify synapomorphies for these large rosid clades, and also for the orders, not only because many larger clades are phylogenetically unresolved, but also because their morphology is not sufficiently understood. It can be expected that synapomorphies will not always be simple character states but rather broader fields of variation - or tendencies to form certain character states or arrays of character states. Rosids remain one of the toughest puzzles for molecular systematics and also for morphology. Fresh structural studies and comparative morphological analyses are greatly needed at all levels, generic, familial, ordinal and supraordinal. We have to tackle this great gap in our knowledge from every possible direction within the framework of the growing phylogenetic knowledge.

This publication is part of a project of the first author financially supported by the Swiss National Foundation (grant no. 3100-059149.99/1), which is gratefully acknowledged.

\section{References}

Adatia R. D., Gavde S. G. (1962) Embryology of the Celastraceae. In: Maheshwari P. (ed.) Plant embryology - a symposium. Council of Scientific and Industrial Research, New Delhi, pp. 1-11.

Agostini G. (1973) El genero Lozania Mutis (Lacistemaceae). Acta Bot. Venezuel. 8: 167-175.

Alimova G. K. (1985a) Bataceae. In: Batygina T. B., Yakovlev M. S. (eds.) Comparative embryology of flowering plants - Brunelliaceae-Tremandraceae. Nauka, Leningrad, pp. 189-191.

Alimova G. K. (1985b) Hippocastanaceae. In: Batygina T. B., Yakovlev M. S. (eds.) Comparative embryology of flowering plants - Brunelliaceae-Tremandraceae. Nauka, Leningrad, pp. 185-188.

Amaral M. do Carmo E. (1991) Phylogenetische Systematik der Ochnaceae. Bot. Jahrb. Syst. 113: 105-195.

APG (2003) An update of the Angiosperm Phylogeny Group classification for the orders and families of flowering plants: APG II. Bot. J. Linn. Soc. 141: 399-436.

Armbruster W. S., Debevec E. M., Willson M. F. (2002) Evolution of syncarpy in angiosperms: theoretical and phylogenetic analyses of the effects of carpel fusion on offspring quantity and quality. J. Evol. Biol. 15: 657-672.

Arora N. (1953) The embryology of Zizyphus rotundifolia Lamk. Phytomorphology 3: 88-98.

Arunalakshmi V. (1989) Structure and development of seed coat in Cleome. J. Ind. Bot. Soc. 68: 116-121.

Atabekova A. I. (1963) Comparative embryological studies in Lupinus (Tourn.) L. Izvest. Timir. Sel'sk. Jaistv. Akad. 2 (51): 219-221.

Barkman T. J., Lim S. H., Salleh K. M., Mais J. (2004) Mitochondrial DNA sequences reveal the photosynthetic relatives of Rafflesia, the world's 
largest flower. Proc. Natl. Acad. Sci. USA 101: 787-792.

Batygina T. B. (2002). Embryology of flowering plants, terminology and concepts I: Generative organs of flowers. Science Publishers, Enfield, N.H.

Bayer C., Kubitzki K. (2002) Malvaceae. In: Kubitzki K., Bayer C. (eds.) The families and genera of vascular plants 5. Springer, Berlin, pp. $225-311$.

Bayer C. (2002) Sarcolaenaceae. In: Kubitzki K., Bayer C. (eds.) The families and genera of vascular plants 5. Springer, Berlin, pp. 345352.

Belyaeva L. E., Fursa N. S. (1981) The embryology of Alliaria officinalis (Brassicaceae) I. Formation of male and female flower structures and the study of the flavonoid composition. Bot. Zhurn. (Moscow and Leningrad) 66: 959-968.

Berg C. C. (1989) Systematics and phylogeny of the Urticales. In: Crane P. R., Blackmore S. B. (eds.) Evolution, systematics, and fossil history of the Hamamelidae. Clarendon Press, Oxford, pp. 193-220.

Berg R. Y. (1975) Fruit, seed, and myrmecochorous dispersal in Micrantheum (Euphorbiaceae). Norweg. J. Bot. 22: 173-194.

Berg R. Y. (1979) Legume, seed, and myrmecochorous dispersal in Kennedia and Hardenbergia (Fabaceae), with a remark on the durian theory. Norweg. J. Bot. 26: 229-254.

Bernard C. (1903) Sur l'embryogénie de quelques plantes parasites. J. Bot. (Paris) 17: 23-32, 6268, 117-137, 168-172, 173-197.

Berry P. E., Hahn W. J., Sytsma K. J., Hall J. C., Mast A. (2004) Phylogenetic relationships and biogeography of Fuchsia (Onagraceae) based on noncoding nuclear and chloroplast DNA data. Amer. J. Bot. 91: 601-614.

Blarer A., Nickrent D., Endress P. K. (2004) Floral structure and systematics in Apodanthaceae (Rafflesiales). Pl. Syst. Evol. 245: 119-142.

Boesewinkel F. D. (1977) Development of ovule and testa in Rutaceae I: Ruta, Zanthoxylum, and Skimmia. Acta Bot. Neerl. 26: 193-211.

Boesewinkel F. D. (1978) Development of ovule and testa in Rutaceae III. Some representatives of the Aurantioideae. Acta Bot. Neerl. 27: 341-354.

Boesewinkel F. D. (1980) Development of ovule and testa of Linum usitatissimum L. Acta Bot. Neerl. 29: 17-32.
Boesewinkel F. D. (1984) Development of ovule and seed coat in Cneorum tricoccum L. (Cneoraceae). Acta Bot. Neerl. 33: 61-70.

Boesewinkel F. D. (1985) The ovule and seed of Humiria balsamifera (Aubl.) St. Hil. Acta Bot. Neerl. 34: 183-191.

Boesewinkel F. D. (1985) Development of ovule and seed-coat in Averrhoa (Oxalidaceae) with notes on some related genera. Acta Bot. Neerl. 34: 413-424.

Boesewinkel F. D. (1987) Ovules and seeds of Trigoniaceae. Acta Bot. Neerl. 36: 81-91.

Boesewinkel F. D. (1999) Ovules and seeds of Tremandraceae. Austral. J. Bot. 47: 769-781.

Boesewinkel F. D., Bouman F. (1978) Development of ovule and testa in Rutaceae II: The unitegmic and pachychalazal seed of Glycosmis cf. arborea (Roxb.) DC. Acta Bot. Neerl. 27: 69-78.

Boesewinkel F. D., Bouman F. (1980) Development of ovule and seed-coat of Dichapetalum mombuttense Engl., with notes on other species. Acta Bot. Neerl. 29: 103-115.

Boesewinkel F. D., Geenen J. (1980) Development of ovule and seed-coat of Erythroxylum coca Lamk. Acta Bot. Neerl. 29: 231-241.

Bohte A., Drinnan A. (2005) Floral development and systematic position of Arillastrum, Allosyncarpia, Stockwellia, Eucalyptopsis (Myrtaceae). Pl. Syst. Evol. 251: 53-70.

Bouman F., Boesewinkel F. D. (1991) The campylotropous ovules and seeds, their structure and functions. Bot. Jahrb. Syst. 113: 255-270.

Bowman J. L. (1994) Arabidopsis: An atlas of morphology and development. Springer, New York.

Carlquist S. (1978) Wood anatomy and relationships of Bataceae, Gyrostemonaceae, and Stylobasiaceae. Allertonia 1: 297-330.

Chaban I. A., Yakovlev M. S. (1974) The embryology of Reseda lutea L. I. Megasporogenesis and development of embryo-sac. Bot. Zhurn. (Moscow and Leningrad) 59: 24-37.

Chandra S., Bhatnagar S. P. (1976) Reproductive biology of Abelmoschus esculentus. IV. Ovule, fertilization, endosperm and embryo development. J. Ind. Bot. Soc. 55: 1-13.

Chikkannaiah P. S., Mahalingappa M. S. (1974) Embryological studies in Ochna squarrosa Linn. Karnatak Univ. J. Sci. 19: 247-249.

Coode M. J. E. (2004) Elaeocarpaceae. In: Kubitzki K. (ed.) The families and genera of 
vascular plants 6. Springer, Berlin, pp. 135144.

Copeland H. F. (1955) The reproductive structures of Pistacia chinensis (Anacardiaceae). Phytomorphology 5: 440-449.

Corner E. J. H. (1964) The life of plants. World Publishing Company, Cleveland, $\mathrm{OH}$.

Corner E. J. H. (1976) The seeds of dicotyledons. Cambridge University Press, Cambridge.

Correll D. S., Correll H. B. (1982) Flora of the Bahama archipelago. Cramer, Vaduz.

Crane P. R., Blackmore S. (eds.) (1989) Evolution, systematics and fossil history of the Hamamelidae. Clarendon Press, Oxford.

Crepet W. L., Nixon K. C., Gandolfo M. A. (2004) Fossil evidence and phylogeny: the age of major angiosperm clades based on mesofossil and macrofossil evidence from Cretaceous deposits. Amer. J. Bot. 91: 1666-1682.

Cronquist A. (1981) An integrated system of classification of flowering plants. Columbia University Press, New York.

Cuatrecasas J. (1970) Brunelliaceae. Flora Neotropica 2: 1-230.

Dahlgren R. M. T. (1980) A revised system of classification of the angiosperms. Bot. J. Linn. Soc. 80: 91-124.

Dahlgren R. M. T., Thorne R. F. (1984) The order Myrtales: circumscription, variation, and relationships. Ann. Missouri Bot. Gard. 71: 633699.

Dathan A. S. R., Singh D. (1971) Embryology and seed development in Bergia L. J. Ind. Bot. Soc. 50: $362-370$.

Dathan A. S. R., Singh D. (1979) Structure and development of female gametophyte and seed in Hydnocarpus laurifolia (Dennst.) Sleumer. J. Ind. Bot. Soc. 58: 256-263.

Davis C. C., Chase M. W. (2004) Elatinaceae are sister to Malpighiaceae; Peridiscaceae belong to Saxifragales. Amer. J. Bot. 91: 262-273.

Davis C. C., Webb C. O., Wurdack K. J., Jaramillo C. A., Donoghue M. J. (2005) Explosive radiation of Malpighiales supports a mid-Cretaceous origin of modern tropical rain forests. Amer. Naturalist 165: E36-E65.

Davis G. L. (1966) Systematic embryology of angiosperms. Wiley, New York.

Dickison W. C. (1990a) A study of the floral morphology and anatomy of the Caryocaraceae. Bull. Torrey Bot. Club 117: 123-137.
Dickison W. C. (1990b) The morphology and relationships of Medusagyne (Medusagynaceae). Pl. Syst. Evol. 171: 27-55.

Dickison W. C., Hils M. H., Lucansky T. W., Stern W. L. (1994) Comparative anatomy and systematics of woody Saxifragaceae. Aphanopetalum Endl. Bot. J. Linn. Soc. 114: 157-182.

Djarwaninshih T. (2004) Revision of Pimelodendron (Euphorbiaceae) in Malesia. Blumea 49: 407-423.

Dnyansagar V. R. (1958) Embryological studies in the Leguminosae. VIII. Acacia auriculaeformis A. Cunn., Adenanthera pavonina Linn., Calliandra haematocephala Hassk., and Calliandra grandiflora Benth. Lloydia 21: 1-25.

Domke W. (1934) Untersuchungen über die systematische und geographische Gliederung der Thymelaeaceen. Bibl. Bot. 111: 1-151.

Donoghue M. J., Doyle J. A. (1989) Phylogenetic analysis of angiosperms and the relationships of Hamamelidae. In: Crane P. R., Blackmore S. (eds.) Evolution, systematics and fossil history of the Hamamelidae I. Clarendon Press, Oxford, pp. 17-45.

Doyle J. A., Hotton C. L. (1991) Diversification of early angiosperm pollen in a cladistic context. In: Blackmore S., Barnes S. H. (eds.) Pollen and spores, patterns of diversification. Clarendon Press, Oxford, pp. 169-195.

Eckardt T. (1937) Untersuchungen über Morphologie, Entwicklungsgeschichte und systematische Bedeutung des pseudomonomeren Gynoeceums. Nova Acta Leopold., n.F., 5, 26: 1-112.

Eckardt T. (1971) Anlegung und Entwicklung der Blüten von Gyrostemon ramulosus Desf. Bot. Jahrb. Syst. 90: 434-446.

Eichler A. W. (1878) Blüthendiagramme 2. Engelmann, Leipzig.

Endress P. K. (1967) Systematische Studie über die verwandtschaftlichen Beziehungen zwischen den Hamamelidaceen und Betulaceen. Bot. Jahrb. Syst. 87: 431-525.

Endress P. K. (1970) Die Infloreszenzen der apetalen Hamamelidaceen, ihre grundsätzliche morphologische und systematische Bedeutung. Bot. Jahrb. Syst. 90: 1-54.

Endress P. K. (1977) Evolutionary trends in the Hamamelidales-Fagales group. Pl. Syst. Evol. (Suppl. 1): 321-347.

Endress P. K. (1978) Blütenontogenese, Blütenabgrenzung und systematische Stellung der peri- 
anthlosen Hamamelidoideae. Bot. Jahrb. Syst. 97: 436-457.

Endress P. K. (1982) Syncarpy and alternative modes of escaping disadvantages of apocarpy in primitive angiosperms. Taxon 31: 48-52.

Endress P. K. (1986) Floral structure, systematics and phylogeny in Trochodendrales. Ann. Missouri Bot. Gard. 73: 297-324.

Endress P. K. (1989) Aspects of evolutionary differentiation of the Hamamelidaceae and the Lower Hamamelididae. P1. Syst. Evol. 162: 193-211.

Endress P. K. (1992) Evolution and floral diversity: The phylogenetic surroundings of Arabidopsis and Antirrhinum. Int. J. Pl. Sci. 153 (6, Suppl.): S106-S122.

Endress P. K. (1999) Symmetry in flowers diversity and evolution. Int. J. Pl. Sci. 160 (6, Suppl.): S3-S23.

Endress P. K. (2003) What should a "complete" morphological phylogenetic analysis entail? In: Stuessy T. F., Hörandl E., Mayer V. (eds.) Deep morphology: Toward a renaissance of morphology in plant systematics. Gantner, Ruggell, pp. 131-164.

Endress P. K. (2005) Links between embryology and evolutionary flower morphology. Curr. Sci. 89: 749-754.

Endress P. K., Igersheim A. (1999) Gynoecium diversity and systematics of the basal eudicots. Bot. J. Linn. Soc. 130: 305-393.

Endress P. K., Matthews M. L. (2006) Elaborate petals and staminodes in eudicots: structure, function, evolution. Org. Div. Evol. (in press).

Endress P. K., Stumpf S. (1990) Non-tetrasporangiate stamens in the angiosperms: structure, systematic distribution and evolutionary aspects. Bot. Jahrb. Syst. 112: 193-240.

Endress P. K., Stumpf S. (1991) The diversity of stamen structures in Lower Rosidae (Rosales, Fabales, Proteales, Sapindales). Bot. J. Linn. Soc. 107: 217-293.

Endress P. K., Jenny M., Fallen M. E. (1983) Convergent elaboration of apocarpous gynoecia in higher advanced dicotyledons (Sapindales, Malvales, Gentianales). Nord. J. Bot. 3: 293-300.

Endriss W. (1902) Monographie von Pilostyles ingae (Karst.) (Pilostyles ulei Solms-Laub.). Flora 91 (Erg.bd.): 1-33.

Engler A. (1925) Guttiferae. In: Engler A., Prantl K. (eds.) Die natürlichen Pflanzenfamilien. 2nd edn. 21. Engelmann, Leipzig, pp. 154-237
Engler A. (1930) Saxifragaceae. In: Engler A., Prantl K. (eds.) Die natürlichen Pflanzenfamilien. 2nd edn. 18a. Engelmann, Leipzig, pp. 74226.

Engler A. (1931a) Burseraceae. In: Engler A., Prantl K. (eds.) Die natürlichen Pflanzenfamilien. 2nd edn. 19a. Engelmann, Leipzig, pp. 405456.

Engler A. (1931b) Rutaceae. In: Engler A., Prantl K. (eds.) Die natürlichen Pflanzenfamilien. 2nd edn. 19a. Engelmann, Leipzig, pp. 187-359.

Engler A., Krause K. (1931) Dichapetalaceae. In: Engler A., Prantl K. (eds.) Die natürlichen Pflanzenfamilien. 2nd edn. 19c. Engelmann, Leipzig, pp. 1-11.

Ernst A., Schmid E. (1913) Über Blüte und Frucht von Rafflesia. Morphologisch-biologische Beobachtungen und entwicklungsgeschichtlich-zytologische Untersuchungen. Ann. Jard. Bot. Buitenzorg, Sér. 2, 12: 1-58.

Fagerlind F. (1944) Die Samenbildung und die Zytologie bei agamospermischen und sexuellen Arten von Elatostema und einigen nahestehenden Gattungen nebst Beleuchtung einiger damit zusammenhängender Probleme. Kungl. Svenska Vetenskapsakad. Handl., Ser. 3, 21 (4): 1-130.

Fellingham A. C., Linder H. P. (2003) Inflorescences of Cliffortia L. (Rosaceae) and related vegetative branching patterns. Bothalia 33: 173-193.

Fey B. S. (1981) Untersuchungen über Bau und Ontogenese der Cupula, Infloreszenzen und Blüten sowie zur Embryologie bei Vertretern der Fagaceae und ihre Bedeutung für die Systematik. Doctoral dissertation, University of Zurich. Von Dach, Lyss.

Fisel K. J., Weberling F. (1990) Untersuchungen zur Morphologie und Ontogenie der Blüten von Tovaria pendula Ruiz \& Pavón und Tovaria diffusa (Macfad.) Fawcett \& Rendle (Tovariaceae). Bot. Jahrb. Syst. 111: 365-387.

Flores E. M., Moseley Jr. M. F. (1982) The anatomy of the pistillate inflorescence and flower of Casuarina verticillata Lamarck (Casuarinaceae). Amer. J. Bot. 69: 1673-1684.

Friis E. M. (1983) Upper Cretaceous (Senonian) floral structures of juglandalean affinity containing Normapolles pollen. Rev. Palaeobot. Palynol. 39: 161-188.

Friis E. M., Crane P. R. (1989) Reproductive structures of Cretaceous Hamamelidae. In: Crane P. R., Blackmore S. (eds.) Evolution, 
systematics, and fossil history of the Hamamelidae I.. Clarendon Press, Oxford, pp. 155-174.

Friis E. M., Pedersen K. R., Schönenberger J. (2003) Endressianthus, a new Normapollesproducing plant genus of fagalean affinity from the Late Cretaceous of Portugal. Int. J. Pl. Sci 164 (5, Suppl.): S201-S223.

Friis E. M., Pedersen K. R., Schönenberger J. (2006) Normapolles plants: prominent components in Cretaceous rosid diversification. Pl. Syst. Evol. 260: 107-140.

Fryxell P. A. (1983) Floral symmetry and zygomorphy in Malvaceae. Amer. J. Bot. 70 (5,2, Abstracts): 58.

Gilg E. (1925) Flacourtiaceae. In: Engler A., Prantl K. (eds.) Die natürlichen Pflanzenfamilien. 2nd edn. 21. Engelmann, Leipzig, pp. 377-457.

Gill G. E., Fowler R. T., Mori S. A. (1998) Pollination biology of Symphonia globulifera (Clusiaceae) in Central French Guiana. Biotropica 30: 139-144.

Gonzalez A. M. (1993) Anatomia y vascularización floral de Piriqueta racemosa, Turnera hassleriana y Turnera joelii (Turneraceae). Bonplandia 7: 143-184.

Guérin P. (1916) Recherches sur la structure anatomique de l'ovule et de la graine des Thyméléacées. Ann. Jard. Bot. Buitenzorg, Sér. 2, 14: 3-35.

Gutzwiller M. (1961) Die phylogenetische Stellung von Suriana maritima L. Bot. Jahrb. Syst. 81: 149

Hakki M. I. (1974) Embryologische Beobachtungen an Succowia balearica (L.) Medik. (Brassicaceae). Bot. Jahrb. Syst. 94: 360-382.

Hall J. C., Sytsma K. J., Iltis H. H. (2002) Phylogeny of Capparaceae and Brassicaceae based on chloroplast sequence data. Amer. J. Bot. 89: 1826-1842.

Hammel B. E., Zamora N. A. (1992) Ruptiliocarpon (Lepidobotryaceae): a new arborescent genus and tropical American link to Africa, with a reconsideration of the family. Novon 3: 408417.

Harms H (1925) Malesherbiaceae. In: Engler A., Prantl K. (eds.) Die natürlichen Pflanzenfamilien. 2nd edn. 21. Engelmann, Leipzig, pp. 467470.

Harms H. (1940) Meliaceae. In: Engler A., Prantl K. (eds.) Die natürlichen Pflanzenfamilien. 2nd edn. 19bI. Engelmann, Leipzig, pp. 1-172.
Haughn G., Chaudhury A. (2005) Genetic analysis of seed coat development in Arabidopsis. Trends Pl. Sci. 10: 472-477.

Heo K., Tobe H. (1994) Embryology and relationships of Suriana maritima L. (Surianaceae). J. Pl. Res. 107: 29-37.

Herendeen P. S., Crane P. R., Drinnan A. N. (1995) Fagaceous flowers, fruits, and cupules from the Campanian (Late Cretaceous) of Central Georgia, USA. Int. J. Pl. Sci. 156: 93116.

Herendeen P. S., Magallón-Puebla S., Lupia R., Crane P. R., Kobylinska J. (1999) A preliminary conspectus of the Allon flora from the Late Cretaceous (Late Santonian) of Central Georgia, U.S.A. Ann. Missouri Bot. Gard. 86: 407-471.

Hermsen E. J. Gandolfo M. A., Nixon K. C., Crepet W. L. (2003) Divisestylus gen. nov., a fossil saxifrage from the Late Cretaceous of New Jersey, USA. Amer. J. Bot. 90: 1373-1388.

Hjelmqvist H. (1953) The embryo sac development of Quercus robur L. Phytomorphology 3: 377384.

Hjelmqvist H. (1956) The embryology of some African Alchemilla species. Bot. Not. 109: 2132.

Horn J. W. (2004) The morphology and relationships of the Sphaerosepalaceae (Malvales). Bot. J. Linn. Soc. 144: 1-40.

Huber H. (1993) Neurada - eine Gattung der Malvales. Sendtnera 1: 7-10.

Hufford L. (1996) Developmental morphology of female flowers of Gyrostemon and Tersonia and floral evolution among Gyrostemonaceae. Amer. J. Bot. 83: 1471-1487.

Hufford L. D., Endress P. K. (1989) The diversity of anther structures and dehiscence patterns among Hamamelididae. Bot. J. Linn. Soc. 99: 301-346.

Igersheim A., Endress P. K. (1998) Gynoecium diversity and systematics of the paleoherbs. Bot. J. Linn. Soc. 127: 289-370.

Iltis H. H. (1999) Setchellanthaceae (Capparales), a new family for a relictual, glucosinolate-producing endemic of the Mexican deserts. Taxon 48: 257-275.

Jenny M. (1988) Different gynoecium types in Sterculiaceae: ontogeny and functional aspects. In: Leins P., Tucker S. C., Endress P. K. (eds.) Aspects of floral development. Cramer, Berlin, pp. 225-236. 
Johri B. M., Ambegaokar K. B., Srivastava P. S. (1992) Comparative embryology of angiosperms 1,2. Springer, Berlin.

Joshi A. C. (1938) A note on the morphology of the gynaecium, ovule and embryo-sac of Psoralea corylifolia. J. Ind. Bot. Soc. 17: 169-172.

Judd W. S., Olmstead R. G. (2004) A survey of tricolpate (eudicot) phylogenetic relationships. Amer. J. Bot. 91: 1627-1644.

Juel H. O. (1915) Über den Bau des Gynaeceums bei Parinarium. Ark. Bot. 14 (7): 1-12.

Juel H. O. (1918) Beiträge zur Blütenanatomie und zur Systematik der Rosaceen. Kungl. Svenska Vetenskapsakad. Handl. 58 (5): 1-81.

Kamalova G. V., Zhukova G. Y., Rumi B. A. (1983) Malvaceae. In: Yakovlev M. S. (ed.) Comparative embryology of flowering plants Phytolaccaceae-Thymelaeaceae. Nauka, Leningrad, pp. 260-266.

Kapil R. N., Maheshwari R. (1964) Embryology of Helianthemum vulgare Gaertn. Phytomorphology 14: 547-557.

Kapil R. N., Bor J., Bouman F. (1980) Seed appendages in angiosperms I. Introduction. Bot. Jahrb. Syst. 101: 555-573.

Kaur A., Jong K., Sands V. E., Soepadmo E. (1986) Cytoembryology of some Malaysian dipterocarps, with some evidence of apomixis. Bot. J. Linn. Soc. 92: 75-88.

Kers L. E. (1970) Studies in Cleome. IV. Cleome elegantissima Briq., C. kermesina Gilg \& Bened. emend. Kers, and C. rubelloides Kers spec. nov. Svensk Bot. Tidskr. 64: 263-283.

Kershaw E. M. (1909) The structure and development of the ovule of Myrica gale. Ann. Bot. 23: 353-362.

Khan R. (1950) A case of twin ovules in Isomeris arborea. Curr. Sci. 19: 326.

Khsetrapal S. (1970) A contribution to the vascular anatomy of the flower of certain species of Salvadoraceae. J. Ind. Bot. Soc. 49: 92-99.

Kloos A., Bouman F. (1980) Case studies in aril development: Passiflora suberosa L. and Turnera ulmifolia L. Beitr. Biol. Pfl. 55: 49-66.

Kopka S., Weberling F. (1984) Zur Morphologie und Morphogenese der Blüte von Vochysia acuminata Bong. subsp. laurifolia (Warm.) Stafleu (Vochysiaceae). Beitr. Biol. Pfl. 59: 273302.

Koehne E. (1903) Lythraceae. In: Engler A. (ed.) Das Pflanzenreich IV.216, Engelmann, Leipzig, pp. 1-326.
Laguna I. G., Cocucci A. E. (1971) El ovario, el ovulo y el megagametofito de Colletia spinosissima (Rhamnaceae). Kurtziana 6: 53-62.

Lam H. J. (1932) Beiträge zur Morphologie der dreizähligen Burseraceae-Canarieae. Bull. Jard. Bot. Buitenzorg 42: 23-56.

Leenhouts P. W. (1978) Systematic notes on the Sapindaceae-Nephelieae. Blumea 24: 395-403.

Leinfellner W. (1972) Zur Morphologie des Gynözeums der Polygalaceen. Österr. Bot. Z. 120: 51-76.

Leins P. (1969) The flower morphology of Emblingia. Bot. J. Linn. Soc. 62: 172-175.

Lewis G., Schrire B., Mackinder B., Lock M. (eds.) (2005) Legumes of the world. Royal Botanic Gardens, Kew.

Lleras E. (1976) Revision and taxonomic position of the genus Euphronia Martius ex Martius \& Zuccarini (Vochysiaceae). Acta Amazon. 6: 43-47.

Macdonald A. D., Sattler R. (1973) Floral development of Myrica gale and the controversy over floral concepts. Canad. J. Bot. 51: 1965-1976.

Maguire B. (1972) Bonnetiaceae. Mem. New York Bot. Gard. 23: 131-165.

Maheshwari P., Johri B. M. (1956) The morphology and embryology of Floerkea proserpinacoides Willd. with a discussion on the systematic position of the family Limnanthaceae. Bot. Mag. (Tokyo) 69: 410-423.

Maheshwari P., Khan R. (1953) Development of the embryo sac, endosperm and embryo in Isomeris arborea - a reinvestigation. Phytomorphology 3: 446-459.

Mametyeva T. B. (1985) Erythroxylaceae. In Batygina T. B., Yakovlev M. S. (eds.) Comparative embryology of flowering plants - Brunelliaceae-Tremandraceae. Nauka, Leningrad, pp. 202-205.

Manos P. S., Zhou Z.-K., Cannon C. H. (2001) Systematics of Fagaceae: phylogenetic tests of reproductive trait evolution. Int. J. Pl. Sci. 162: 1361-1379.

Matthews M. L., Endress P. K. (2002) Comparative floral structure and systematics in Oxalidales (Oxalidaceae, Connaraceae, Cephalotaceae, Brunelliaceae, Cunoniaceae, Elaeocarpaceae, Tremandraceae). Bot. J. Linn. Soc. 140: 321381.

Matthews M. L., Endress P. K. (2004) Comparative floral structure and systematics in Cucurbitales (Corynocarpaceae, Coriariaceae, 
Datiscaceae, Tetramelaceae, Begoniaceae, $\mathrm{Cu}$ curbitaceae, Anisophylleaceae). Bot. J. Linn. Soc. 145: 129-185.

Matthews M. L., Endress P. K. (2005a) Comparative floral structure and systematics in Crossosomatales (Crossosomataceae, Stachyuraceae, Staphyleaceae, Aphloiaceae, Geissolomataceae, Ixerbaceae, Strasburgeriaceae). Bot. J. Linn. Soc. 147: 1-46.

Matthews M. L., Endress P. K. (2005b) Comparative floral structure and systematics in Celastrales (Celastraceae, Parnassiaceae, Lepidobotryaceae). Bot. J. Linn. Soc. 149: 129-194.

Matthews M. L., Endress P. K. (2006) Floral structure and systematics in orders of rosids, including a survey of floral mucilage cells. Pl. Syst. Evol. 260: 199-221.

Matthews M. L., Endress P. K., Schönenberger J., Friis E. M. (2001) A comparison of floral structures of Anisophylleaceae and Cunoniaceae and the problem of their systematic position. Ann. Bot. 88: 439-455.

Mauritzon J. (1930) Beitrag zur Embryologie der Crassulaceen. Bot. Not. 1933: 543-554.

Mauritzon J. (1935) Die Embryologie einiger Capparidaceen sowie von Tovaria pendula. Ark. Bot. 26A (15): 1-14.

Mauritzon J. (1936) Zur Embryologie einiger Parietales-Familien. Svensk Bot. Tidskr. 30: 79-113.

Mauritzon J. (1939) Contributions to the embryology of the orders Rosales and Myrtales. Lunds Univ. Arsskr., n.F., Avd. 2, 35 (2): 1-121.

Mehta I. J., Moseley Jr. M. F. (1981) The floral anatomy of Koeberlinia Zucc.: systematic implications. Amer. J. Bot. 68: 482-497.

Melville R. (1969) The floral vascular system of Emblingia. Bot. J. Linn. Soc. 62: 175-182.

Merino Sutter D., Endress P. K. (2003) Structure of female flowers and cupules in Balanopaceae, an enigmatic rosid family. Ann. Bot. 92: 459-469.

Merino Sutter D., Forster P. A., Endress P. K. (2006) Female flowers and systematic position of Picrodendraceae (Euphorbiaceae s.l., Malpighiales). Pl. Syst. Evol. (in press).

Mitchell J. D., Mori S. A. (1987) The cashew and its relatives (Anacardium: Anacardiaceae). Mem. New York Bot. Gard. 42: 1-76.

Moody M., Hufford L. (2000) Floral development and structure of Davidsonia. Canad. J. Bot. 78: 1034-1043.
Murbeck S. (1916) Über die Organisation, Biologie und verwandtschaftlichen Beziehungen der Neuradoideen. Lunds Univ. Arsskr., Avd. 2, 12 (6): 1-32.

Murgai P. (1962) Embryology of Paeonia together with a discussion on its systematic position. In: Maheshwari P. (ed.) Plant embryology - a symposium. Council of Scientific and Industrial Research, New Delhi, pp. 215-223.

Murguía-Sánchez G., Novelo R. A., Philbrick C. T., Márquez-Guzmán G. J. (2002) Embryo sac development in Vanroyenella plumosa, Podostemaceae. Aquat. Bot. 73: 201-210.

Murty Y. S., Gupta S. (1978) Morphological studies in Meliaceae. II. A reinvestigation of floral anatomy of members of Swietenieae and Trichilieae. Proc. Ind. Acad. Sci. B 87: 55-64.

Nagendran C. R., Dinesh M. S. (1989) The embryology of angiosperms: a classified bibliography (1965-1985). Indira Publishing House, Oak Park, Michigan, USA.

Nair N. C., Joseph T. C. (1957) Floral morphology and embryology of Samadera indica. Bot. Gaz. 119: 104-115.

Nair N. C., Sukumaran N. P. (1960) Floral morphology and embryology of Brucea amarissima. Bot. Gaz. 121: 175-185.

Nandi O. I. (1998a) Floral development and systematics of Cistaceae. Pl. Syst. Evol. 212: 107-134.

Nandi O. I. (1998b) Ovule and seed anatomy of Cistaceae and related Malvanae. Pl. Syst. Evol. 209: 239-246.

Nandi O. I., Chase, M. W., Endress, P. K. (1998) A combined cladistic analysis of angiosperms using $r b c \mathrm{~L}$ and nonmolecular data sets. Ann. Missouri Bot. Gard. 85: 137-212.

Narayana H. S. (1962) Studies in the Capparidaceae - I. The embryology of Capparis decidua (Forsk.) Pax). Phytomorphology 12: 167-177.

Narayana L. L. (1957) Embryology of two Simaroubaceae. Curr. Sci. 26: 323-324.

Narayana L. L. (1959) Floral anatomy of Meliaceae - II. J. Ind. Bot. Soc. 38: 288-295.

Narayana L. L. (1960) Studies in Burseraceae - II. J. Ind. Bot. Soc. 39: 402-409.

Narayana L. L. (1963) A contribution to the floral anatomy and embryology of Linaceae. J. Ind. Bot. Soc. 43: 343-357.

Narayana L. L. (1970) Linaceae. Bull. Ind. Natl. Sci. Acad. 41: 127-132. 
Narayana L. L. (1973) A contribution to the floral anatomy and embryology of Ochnaceae. J. Jap. Bot. 50: 329-336.

Narayana L. L., Rao D. (1969) Contributions to the floral anatomy of Humiriaceae 1. J. Jap. Bot. 44: 328-335.

Narayana L. L., Rao D. (1971) Contributions to the floral anatomy of Linaceae II. Phytomorphology 21: 64-67.

Nast C. G. (1935) Morphological development of the fruit of Juglans regia. Hilgardia 9: $345-$ 381.

Nickrent D. L., Blarer A., Qiu Y. L., Vidal-Russell R., Anderson F. E. (2004) Phylogenetic inference in Rafflesiales: the influence of rate heterogeneity and horizontal gene transfer. BMC Evol. Biol. 4: Art. No. 40. (on-line publication).

Nickrent D. L., Der J. P., Anderson F. E. (2005) Discovery of the photosynthetic relatives of the "Maltese mushroom" Cynomorium. BMC Evol. Biol. 5: Art. No. 38 (on-line publication).

Nikiticheva Z. I., Yakovlev M. S. (1985) Rhizophoraceae. In: Batygina T. B., Yakovlev M. S. (eds.) Comparative embryology of flowering plants - Brunelliaceae-Tremandraceae. Nauka, Leningrad, pp. 120-125.

Olson M. E. (2003) Ontogenetic origins of floral bilateral symmetry in Moringaceae (Brassicales). Amer. J. Bot. 90: 49-71.

Orchard A E. (1975) Taxonomic revisions in the family Haloragaceae. I. The genera Haloragis, Haloragodendron, Glischrocaryon, Meziella and Gonocarpus. Bull. Auckland Inst. Mus. 10: 1-299.

Paetow W. (1931) Embryologische Untersuchungen an Taccaceen, Meliaceen und Dilleniaceen. Planta 14: 441-470.

Pax F., Hoffmann K. (1936) Capparidaceae. In: Engler A., Prantl K. (eds.) Die natürlichen Pflanzenfamilien. 2nd edn. 17b. Engelmann, Leipzig, pp. 146-223.

Peng Y. L., Chen Z. D., Gong X., Zhong Y., Shi S. H. (2003) Phylogenetic position of Dipentodon sinicus: evidence from DNA sequences of chloroplast $r b c \mathrm{~L}$, nuclear ribosomal $18 \mathrm{~S}$, and mitochondrial matR genes. Bot. Bull. Acad. Sin. 44: 217-222.

Periasamy K., Indira C. (1986) The carpel of Moringa. Ann. Bot. 58: 897-901.

Phatak V. G. (1971) Embryology of Zygophyllum coccineum L. and $Z$. fabago L. Proc. Kon. Ned. Akad. Wet. 74: 379-397.
Poole A. L. (1952) The development of Nothofagus seed (including a preliminary account of the embryogeny, etc.). Trans. Roy. Soc. New Zeal. 80: 207-212.

Poppendieck H.-H. (1980) A monograph of the Cochlospermaceae. Bot. Jahrb. Syst. 101: 191265.

Prakash N., Lau Y. Y. (1976) Morphology of Ploiarium alternifolium and the taxonomic position of Ploiarium. Bot. Not. 129: 279-285.

Prakash N., Lim A. L., Manurung R. (1977) Embryology of duku and langsat varieties of Lansium domesticum. Phytomorphology 27: 5059.

Prance G. T., White F. (1988) The genera of Chrysobalanaceae: a study in practical and theoretical taxonomy and its relevance to evolutionary biology. Philos. Trans. Roy. Soc. London B 320: 1-184.

Puri V. (1939) Studies in the order Parietales II. A contribution to the morphology of Garcinia livingstonii T. Anders. Proc. Ind. Acad. Sci. 9: 74-86.

Puri V. (1941) The life-history of Moringa oleifera Lamk. J. Ind. Bot. Soc. 20: 263-284.

Puri V. (1942) Studies in floral anatomy. II. Floral anatomy of Moringaceae with special reference to gynaeceum constitution. Proc. Natl. Inst. Sci. India 8: 71-88.

Radcliffe-Smith A. (2001) Genera Euphorbiacearum. Royal Botanic Gardens, Kew.

Ramp E. (1987) Funktionelle Anatomie des Gynoeciums bei Staphylea. Bot. Helv. 97: 89-98.

Ramp E. (1988) Struktur, Funktion und systematische Bedeutung des Gynoeciums bei den Rutaceae und Simaroubaceae. Doctoral dissertation, University of Zurich. ADAG, Zurich.

Rao A. N. (1955) A contribution to the embryology of Vateria indica Linn. Proc. Natl. Inst. Sci. India 21: 247-255.

Rao A. N. (1957) The embryology of Hypericum patulum Thunb. and H. mysorense Heyne. Phytomorphology 7: 36-45.

Rao A. N. (1962) Floral anatomy and gametogenesis in Hopea racophloea Dyer. J. Ind. Bot. Soc. 41: 226-242.

Rao C. V. (1949) Contributions to the embryology of Sterculiaceae - I. J. Ind. Bot. Soc. 28: 180197.

Rao C. V. (1952) The embryology of Muntingia calabura L. J. Ind. Bot. Soc. 31: 87-101. 
Rao C. V. (1954) Contributions to the embryology of Sterculiaceae - V. J. Ind. Bot. Soc. 32: 208238.

Rao D., Narayana L. L. (1955) Embryology of Linaceae. Curr. Sci. 34: 92-93.

Rao V. S. (1974) The nature of the perianth in Elaeagnus on the basis of floral anatomy, with some comments on the systematic position of Elaeagnaceae. J. Ind. Bot. Soc. 53: 156-161.

Rao V. S., Gupte K. (1957) The pistil of Ochna squarrosa Linn. Curr. Sci. 26: 215-216.

Razi B. A. (1955) Some aspects of the embryology of Zeylanidium olivaceum (Tul.) Engl., and Lawia zeylanica Tul. Bull. Bot. Soc. Bengal 9: 36-41.

Rodionova G. B. (1983) Capparaceae. In: Yakovlev M. S. (ed.) Comparative embryology of flowering plants - Phytolaccaceae-Thymelaeaceae. Nauka, Leningrad, pp. 150-154.

Rollins R. C. (1963) Protandry in two species of Streptanthus (Cruciferae). Rhodora 65: 45-49.

Ronse De Craene L. P. (2002) Floral development and anatomy of Pentadiplandra (Pentadiplandraceae): a key genus in the identification of floral morphological trends in the core Brassicales. Canad. J. Bot. 80: 443-459.

Ronse De Craene L. P., Miller A. G. (2004) Floral development and anatomy of Dirachma socotra$n a$ (Dirachmaceae): a controversial member of the Rosales. Pl. Syst. Evol. 249: 111-127.

Ronse De Craene L. P., Smets E. (1995) The floral development of Neurada procumbens L. (Neuradaceae). Acta Bot. Neerl. 44: 439-451.

Ronse De Craene L. P., Smets E. F. (1996) Morphological studies in Zygophyllaceae. II. The floral development and vascular anatomy of Peganum harmala. Amer. J. Bot. 83: 201-215.

Ronse De Craene L. P., Smets E. F. (1997) Evidence for carpel multiplication in the Capparaceae. Belg. J. Bot. 130: 59-67.

Ronse De Craene L. P., Smets E. (1999) The floral development and anatomy of Carica papaya (Caricaceae). Canad. J. Bot. 77: 582-598.

Ronse De Craene L. P., Smets E. (2001) Floral developmental evidence for the systematic relationships of Tropaeolum (Tropaeolaceae). Ann. Bot. 88: 879-892.

Ronse De Craene L. P., Smets E., Clinckemaillie D. (2000) Floral ontogeny and anatomy in Koelreuteria with special emphasis on monosymmetry and septal cavities. Pl. Syst. Evol. 223: 91107.

Ronse De Craene L. P., Yang, T. Y. A., Schols P., Smets E. F. (2002) Floral anatomy and systematics of Bretschneidera (Bretschneideraceae). Bot. J. Linn. Soc. 139: 29-45.

Sanderson M. J., Hufford L. (eds.) (1996) Homoplasy: the recurrence of similarity in evolution. Academic Press, San Diego.

Sastri R. L. N. (1958). Floral morphology and embryology of some Dilleniaceae. Bot. Not. 111: 495-511.

Savolainen V., Fay M. F., Albach D. C., Backlund A., van der Bank M., Cameron K. M., Johnson S. A., Lledó M. D., Pintaud J.-C., Powell M., Sheahan M. C., Soltis D. E., Soltis P. S., Weston P., Whitten W. M., Wurdack K. J., Chase M. W. (2000) Phylogeny of the eudicots: a nearly complete familial analysis based on $r b c \mathrm{~L}$ gene sequences. Kew Bull. 55: 257-309.

Sazima M., Sazima I. (1978) Bat pollination of the passion flower, Passiflora mucronata, in southeastern Brazil. Biotropica 10: 100-109.

Schnarf K. (1931a) Ein Beitrag zur Samenentwicklung der Gattung Cochlospermum. Österr. Bot. Z. 80 : $45-50$.

Schnarf K. (1931b) Vergleichende Embryologie der Angiospermen. Borntraeger, Berlin.

Schneider J. V., Swenson U., Zizka G. (2002) Phylogenetic reconstruction of the Neotropical family Quiinaceae (Malpighiales) based on morphology with remarks on the evolution of an androdioecious sex distribution. Ann. Missouri Bot. Gard. 89: 54-76.

Schönenberger J., von Balthazar M. (2006) Reproductive structures and phylogenetic framework of the rosides - progress and prospects. Pl. Syst. Evol. 260: 87-106.

Schönenberger J., Conti E. (2003) Molecular phylogeny and floral evolution of Penaeaceae, Oliniaceae, Rhynchocalycaceae, and Alzateaceae (Myrtales). Amer. J. Bot. 90: 293-309.

Schönenberger J., Friis E. M., Matthews M. L., Endress P. K. (2001) Cunoniaceae in the Cretaceous of Europe: evidence from fossil flowers. Ann. Bot. 88: 423-437.

Schönenberger J., Pedersen K. R., Friis E. M. (2001) Normapolles flowers of fagalean affinity from the Late Cretaceous of Portugal. Pl. Syst. Evol. 226: 205-230. 
Setoguchi H., Ohba H., Tobe H. (1996) Floral morphology and phylogenetic analysis in Crossostylis (Rhizophoraceae). J. Pl. Res. 109: 7-19.

Shamrov I. I. (1999) The ovule as the base of seed reproduction in flowering plants: classification of the structures. Bot. Zhurn. (St. Petersburg) 84 (1): $1-35$.

Sharma M. K., Narayana H. S. (1971) Development of male and female gametophytes in Prinsepia utilis Royle. Curr. Sci. 40: 7-8.

Shattuck C. H. (1905) A morphological study of Ulmus americana. Bot. Gaz. 40: 209-223.

Shukla R. D. (1954) Gametophytes in Balsamodendron mukul Hook. Curr. Sci. 23: 333.

Simmons S. L., Panero J. L., Chase M. W. (1998) Molecular systematics of Staphyleaceae: a reevaluation of its composition, ordinal placement, intra- and infrageneric relationships as inferred from $r b c \mathrm{~L}$ and ITS sequence data. Amer. J. Bot. 85(6, Abstr.): 155.

Sims H. J., Herendeen P. S., Crane P. R. (1998) New genus of fossil Fagaceae from the Santonian (Late Cretaceous) of Central Georgia, U. S. A. Int. J. Pl. Sci. 159: 391-404.

Sims H. J., Herendeen P. S., Lupia R., Christopher R. A., Crane P. R. (1999) Fossil flowers with Normapolles pollen from the Upper Cretaceous of southeastern North America. Rev. Palaeobot. Palynol. 106: 131-151.

Singh D., Gupta S. (1968) The seeds of the Violaceae and Resedaceae - a comparison. J. Ind. Bot. Soc. 46: 248-256.

Singh R. P. (1970) Structure and development of seeds in Putranjiva roxburghii Wall. J. Ind. Bot. Soc. 49: 99-105.

Singh R. P. (1972) Structure and development of seed in Phyllanthus niruri L. J. Ind. Bot. Soc. 51: 73-77.

Sleumer H. (1942) Icacinaceae. In: Engler A., Prantl K. (eds.) Die natürlichen Pflanzenfamilien. 2nd edn. 20b. Engelmann, Leipzig, pp. 322396.

Sobick U. (1983) Blütenentwicklungsgeschichtliche Untersuchungen an Resedaceen unter besonderer Berücksichtigung von Androeceum und Gynoeceum. Bot. Jahrb. Syst. 104: 203-248.

Sogo A., Noguchi J., Jaffré T., Tobe H. (2004) Pollen-tube growth pattern and chalazogamy in Casuarina equisetifolia (Casuarinaceae). J. Pl. Res. 117: 37-46.
Sogo A., Tobe H. (2005) Intermittent pollen-tube growth in pistils of alders (Alnus). Proc. Natl. Acad. Sci. USA 102: 8770-8775.

Soltis D. E., Soltis P. S., Morgan D. R., Swensen S. M., Mullin B. C., Dowd J. M., Martin P. G. (1995) Chloroplast gene sequence data suggest a single origin of the predisposition for symbiotic nitrogen fixation in angiosperms. Proc. Natl. Acad. Sci. USA 92: 2647-2651.

Soltis D. E., Soltis P. S., Chase M. W., Mort M. E., Albach D. C., Zanis M., Savolainen V., Hahn W. H., Hoot S. B., Fay M. F., Axtell M., Swensen S. M., Prince L. M., Kress W. J., Nixon K. C., Farris J S. (2000) Angiosperm phylogeny inferred from $18 \mathrm{~S}$ rDNA, $r b c \mathrm{~L}$, and $a t p \mathrm{~B}$ sequences. Bot. J. Linn. Soc. 133: 381-461.

Soltis D. E., Soltis P. S., Endress P. K., Chase M. W. (2005) Phylogeny and evolution of angiosperms. Sinauer, Sunderland, Mass.

Starshova N. P., Solntseva M. P. (1973) To the characteristic of the embryo sac of Phellodendron amurense Rupr. Bot. Zhurn. (Moscow and Leningrad) 58: 1644-1654.

Steindl F. (1945) Beitrag zur Pollen- und Embryobildung bei Cynomorium coccineum. Arch. Julius Klaus-Stiftg. 20: 342-355.

Stenar H. (1925) Embryologische und zytologische Studien über Limnanthes douglasii R. Br. Svensk Bot. Tidskr. 19: 133-152.

Stephens E. L. (1910) The development of the seedcoat of Carica papaya. Ann. Bot. 24: 607-610.

Stevens P. F. (2001 onwards.) The angiosperm phylogeny website. http//www.mobot.org/ MOBOT/research/Apweb/welcome/

Steyermark J. A., Luteyn I. L. (1980) Revision of the genus Ochthocosmus (Linaceae). Brittonia 32: 128-143.

Steyn E. M. A., van Wyk A. E., Smith G. F. (2002) A study of ovule-to-seed development in Ceratiosicyos (Achariaceae) and the systematic position of the genus. Bothalia 32: 201-210.

Steyn E. M. A., Smith G. F., van Wyk A. E. (2004) Functional and taxonomic significance of seed structure in Salix mucronata (Salicaceae). Bothalia 34: 53-59.

Steyn E. M. A., van Wyk A. E., Smith G. F. (2005) Ovule-to-seed development in Dovyalis caffra (Salicaceae: Flacourtiaceae) with notes on the taxonomic significance of the extranucellar embryo sac. Bothalia 35: 101-108. 
Subramanyam K. (1968) Some aspects of the embryology of Sedum chrysanthum (Boissier) Raymond-Hamlet with a dicussion on its systematic position. Phytomorphology 17: 240247.

Sumner M. J., Van Caesele L. (1988) Ovule development in Brassica campestris: a light microscope study. Canad. J. Bot. 66: 2459-2469.

Sutter D. (1994) Gynoeciumstruktur und Grossystematik bei Euphorbiaceae. Unpublished Masters Thesis, University of Zurich.

Sutter D., Endress P. K. (1995) Aspects of gynoecium structure and macrosystematics in Euphorbiaceae. Bot. Jahrb. Syst. 116: 517-536.

Swensen S. M. (1996) The evolution of actinorhizal symbioses: evidence for multiple origins of the symbiotic association. Amer. J. Bot. 83: 15031512.

Takhtajan A. (1987) Systema Magnoliophytorum. Nauka, Leningrad.

Takhtajan A. (1997) Diversity and classification of flowering plants. Columbia University Press, New York.

Thorne R. F. (1992) Classification and geography of the flowering plants. Bot. Rev. 58: 225-348.

Tobe H. (1991) Reproductive morphology, anatomy and relationships of Ticodendron. Ann. Missouri Bot. Gard. 78: 135-142.

Tobe H., Peng C.-I. (1990) The embryology and taxonomic relationships of Bretschneidera (Bretschneideraceae). Bot. J. Linn. Soc. 103: 139-152.

Tobe H., Raven P. H. (1984) An embryological contribution to systematics of the Chrysobalanaceae. I. Tribe Chrysobalaneae. Bot. Mag (Tokyo) 97: 397-411.

Tobe H., Raven P. H. (1987a) Systematic embryology of the Anisophylleaceae. Ann. Missouri Bot. Gard. 74: 1-26.

Tobe H., Raven P. H. (1987b) The embryology and relationships of Cassipourea and Sterigmapetalum (Rhizophoraceae-Macarisieae). Opera Bot. 92: 253-264.

Tobe H., Raven P. H. (1988a) Floral morphology and evolution in Anisophylleaceae. Bot. J. Linn. Soc. 98: 1-25.

Tobe H., Raven P. H. (1988b) Seed morphology and anatomy of Rhizophoraceae, inter- and infrafamilial relationships. Ann. Missouri Bot. Gard. 75: 1319-1342.
Tobe H., Raven P. H. (1995) Embryology and relationships of Akania (Akaniaceae). Bot. J. Linn. Soc. 118: 261-274.

Tobe H., Carlquist S., Iltis H. H. (1999) Reproductive anatomy of Setchellanthus caeruleus (Setchellanthaceae). Taxon 48: 277-283.

Tokuoka T., Tobe H. (1995) Embryology and systematics of Euphorbiaceae sens.lat.: a review and perspective. J. Pl. Res. 108: 97-106.

Tokuoka T., Tobe H. (1999) Embryology of tribe Drypeteae, an enigmatic taxon of Euphorbiaceae. Pl. Syst. Evol. 215: 189-208.

Tokuoka T., Tobe H. (2001) Ovules and seeds in subfamily Phyllanthoideae (Euphorbiaceae): structure and systematic implications. J. Pl. Res. 114: 75-92.

Tokuoka T., Tobe H. (2002) Ovules and seeds in Euphorbioideae (Euphorbiaceae): structure and systematic implications. J. Pl. Res. 116: 355-380.

Tokuoka T., Tobe H. (2003) Ovules and seeds in Acalyphoideae (Euphorbioideae): structure and systematic implications. J. Pl. Res. 116: 355380.

Tomlinson P. B. (1980) The biology of trees native to tropical Florida. P. B. Tomlinson, Allston, MA.

Treub M. (1911) Le sac embryonnaire et l'embryon dans les angiospermes. Nouvelle série des recherches. Ann. Jard. Bot. Buitenzorg 24: 1-17.

Tucker S. C. (1992) The role of floral development in studies of legume evolution. Canad. J. Bot. 70: 692-700.

van der Pijl L. (1957) On the arilloids of Nephelium, Euphoria, Litchi and Aesculus, and the seeds of Sapindaceae in general. Acta Bot. Neerl. 6: 618641.

van Heel W. A. (1967) Anatomical and ontogenetic investigations on the morphology of the flowers and the fruit of Scyphostegia borneensis Stapf (Scyphostegiaceae). Blumea 15: 107-125.

van Heel W. A. (1979) Flowers and fruits in Flacourtiaceae, IV. Hydnocarpus spp., Kiggelaria africana L., Casearia spp., Berberidopsis corallina Hook. f. Blumea 25: 513-529.

van Heel W. A. (1984) Flowers and fruits in Flacourtiaceae. V. The seed anatomy and pollen morphology of Berberidopsis and Streptothamnus. Blumea 30: 31-37.

Venkateswarlu J. (1947) Embryological studies in the Thymelaeaceae II. Daphne cannabina Wall. 
and Wikstroemia canescens Meissn. J. Ind. Bot. Soc. 26: 13-39.

Verhoog H. (1968) A contribution towards the developmental gynoecium morphology of Engelhardia spicata Lechen. ex Blume (Juglandaceae). Acta Bot. Neerl. 17: 137-150.

Verkerke W. (1985). Ovules and seeds of the Polygalaceae. J. Arnold Arbor. 66: 353-394.

Vogel S. (1954) Blütenbiologische Typen als Elemente der Sippengliederung. Fischer, Jena.

Vogel S. (1990) History of the Malpighiaceae in the light of pollination ecology. Mem. New York Bot. Gard. 55: 130-142.

von Balthazar M., Nyffeler R. (2002) The peculiar androecium of Cullenia (Durioneae, Malvaceae s.1.). In: Schönenberger J., von Balthazar M., Matthews M. L. (eds.) Flowers: diversity, development and evolution. Institute of Systematic Botany, University of Zürich, Zürich, p. 89.

Walters J. L. (1962) Megasporogenesis and gametophyte selection in Paeonia californica. Amer. J. Bot. 49: 787-794.

Webster G. L. (1994) Synopsis of the genera and suprageneric taxa of Euphorbiaceae. Ann. Missouri Bot. Gard. 81: 33-144.

Weckerle C. S., Rutishauser R. (2003) Comparative morphology and systematic position of Averrhoidium within Sapindaceae. Int. J. Pl. Sci. 164: 775-792.

Weckerle C. S., Rutishauser R. (2005) Gynoecium, fruit and seed structure of Paullinieae (Sapindaceae). Bot. J. Linn. Soc. 147: 159-189.
Wiger J. (1935) Embryological studies on the families Buxaceae, Meliaceae, Simarubaceae and Burseraceae. Doctoral dissertation, University of Lund. Gleerup, Lund.

Winkler H. (1931) Linaceae. In: Engler A., Prantl K. (eds.) Die natürlichen Pflanzenfamilien. 2nd edn. 19a. Engelmann, Leipzig, pp. 82-130.

Wisniewski M., Bogle A. L. (1982) The ontogeny of the inflorescence and flower of Liquidambar styraciflua L. (Hamamelidaceae). Amer. J. Bot. 69: $1612-1624$.

Yamazaki T. (1982) The seed formation of Fatoua villosa Nakai (Moraceae). J. Jap. Bot. 57: 6-13.

Zhang L.-B., Simmons M. P. (2006) Phylogeny and delimitation of the Celastrales inferred from nuclear and plastid genes. Syst. Bot. 31: 122-137.

Zhang Z.-Y., Chen Z.-D. (1993) Embryology of Carpinus turczaninowii (Betulaceae) and its systematic significance. Cathaya 5: 59-68.

Zhang Z.-Y., Lu A.-M., Wen J. (1994) Embryology of Rhoiptelea chiliantha (Rhoipteleaceae) and its systematic relationship. Cathaya 6: 57-66.

Address of the authors: Peter K. Endress (e-mail: pendress@systbot.unizh.ch) and Merran L. Matthews (e-mail: mmatthews@access.unizh.ch), Institute of Systematic Botany, University of Zurich, Zollikerstrasse 107, 8008 Zurich, Switzerland. 